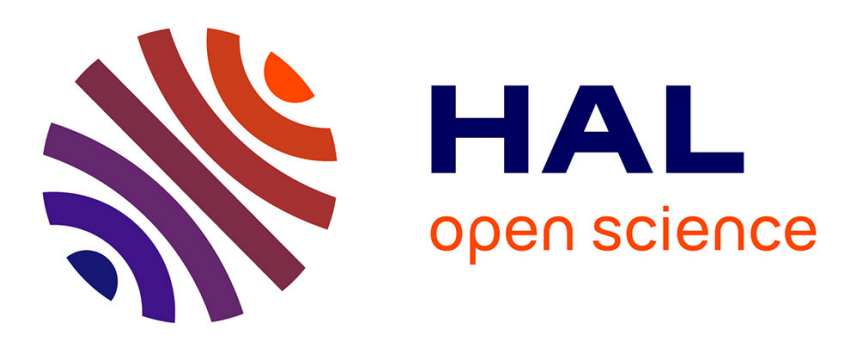

\title{
Evidence of microbial activity from a shallow water whale fall (Voghera, northern Italy)
}

S. Danise, B. Cavalazzi, S. Dominici, Frances Westall, S. Monechi, S. Guioli

\section{To cite this version:}

S. Danise, B. Cavalazzi, S. Dominici, Frances Westall, S. Monechi, et al.. Evidence of microbial activity from a shallow water whale fall (Voghera, northern Italy). Palaeogeography, Palaeoclimatology, Palaeoecology, 2012, 317-318, pp.13-26. 10.1016/j.palaeo.2011.12.001 . insu-01334173

\section{HAL Id: insu-01334173 https://hal-insu.archives-ouvertes.fr/insu-01334173}

Submitted on 7 Dec 2019

HAL is a multi-disciplinary open access archive for the deposit and dissemination of scientific research documents, whether they are published or not. The documents may come from teaching and research institutions in France or abroad, or from public or private research centers.
L'archive ouverte pluridisciplinaire HAL, est destinée au dépôt et à la diffusion de documents scientifiques de niveau recherche, publiés ou non, émanant des établissements d'enseignement et de recherche français ou étrangers, des laboratoires publics ou privés. 
1 Evidence of microbial activity form a Miocene shallow water whale fall (Voghera, northern

2 Italy)

3

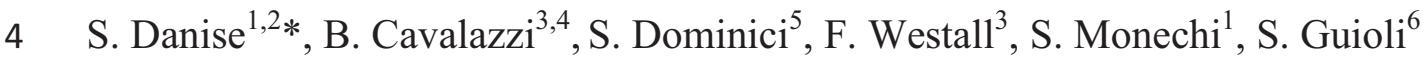

5

6

$7 \quad{ }^{1}$ Dipartimento di Scienze della Terra, Università degli Studi di Firenze, via La Pira 4, 50121,

8 Firenze, Italy.

$9 \quad{ }^{2}$ Present address: School of Geography, Earth and Environmental Sciences, University of

Plymouth, Drake Circus, Plymouth, Devon, PL4 8AA, United Kingdom.

${ }^{3}$ Centre de Biophysique Moléculaire, CNRS, Rue Charles Sadron, Orléans cedex 2, 45071, France.

${ }^{4}$ Department of Geology, University of Johannesburg, Kingsway Campus, PO Box 524 Auckland Park, 2006 South Africa.

${ }^{5}$ Museo di Storia Naturale, Sezione di Geologia e Paleontologia, Università degli Studi di Firenze, via La Pira 4, 50121, Firenze, Italy.

${ }^{6}$ Civico Museo di Scienze Naturali di Voghera, Via Gramsci 1, 27058 Voghera, Pavia, Italy. *corresponding author. Tel: +44 (0)1752 584874. E-mail : silvia.danise@plymouth.ac.uk

\section{ABSTRACT}

The fossil bones, associated carbonate cements and enclosing concretion of a Miocene mysticete from inner shelf deposits (Monte Vallassa Formation, northern Italy) were analyzed for evidence of microbial activity. Optical and scanning electron microscopy, Raman spectroscopy, and stable C 
and $\mathrm{O}$ isotope geochemistry were used for high spatial resolution microfacies and biosedimentological analyses. Whale cancellous bones were filled by different carbonate cements including microcrystalline dolomite, rhombohedral dolomite and sparry calcite. Biofabric and biominerals such as microbial peloids, clotted textures and pyrite framboids were associated with the dolomite cements. Dolomite inside cancellous bones and in the enclosing concretion showed similar isotopic values $\left(\operatorname{avg} \delta^{13} \mathrm{C}:-7.12 \%\right.$; avg $\delta^{18} \mathrm{O}:+3.81 \%$ ), depleted with respect to the (late) sparry calcite cement $\left(\operatorname{avg} \delta^{13} \mathrm{C}:-0.55 \%\right.$; avg $\delta^{18} \mathrm{O}:-0.98 \%$ ). Microcrystalline barite $\left(\mathrm{BaSO}_{4}\right)$ was observed on the external surface of the bones. In addition, two different types of microborings were recognized, distinguished by their size and morphology and were ascribed respectively to prokaryote and fungal trace makers. Our results testify for the development of a diverse microbial ecosystem during the decay of a shallow water whale carcass, which could be detected in the fossil record. However, none of the observed biosignatures (e.g., microbial peloids, clotted textures) can be used alone as a positive fossil evidence of the general development of a sulfophilic stage of whale fall ecological succession. The occurrence of the hard parts of chemosynthetic invertebrates associated with fossil whale bones is still the more convincing proof of the development of a sulfide-base chemoautotrophic ecosystem.

KEYWORDS: whale fall; microbial activity; carbonate biofabrics; microborings.

\section{Introduction}

Dead whales sunk to the deep sea floor create persistent and ecologically significant habitats that can support a diverse and highly specialized community (Smith, 2006). Sharks, hagfishes and other scavenging organisms remove flash and soft tissues ("mobile scavenger stage"), polychaetes, 
crustaceans and other opportunistic small-sized animals thrive on whale organic remains ("enrichment opportunist stage"), while a long lasting and complex community relies on the hydrogen sulfide $\left(\mathrm{H}_{2} \mathrm{~S}\right)$ and other chemical compounds produced by microbial consumption of the lipid-rich bones ("sulfophilic stage"; Smith and Baco, 2003). In modern oceans the sediments beneath and around whale carcasses, progressively enriched with lipids and other organic compounds (Naganuma et al., 1996; Smith et al., 1998), experience anoxic conditions due to high microbial oxygen consumption that favors anaerobic processes such as sulfate reduction and methanogenesis (Allison et al., 1991). Whale carcasses and the surrounding sediments represent thus a suitable habitat for sulfide-based chemosynthetic communities as well as sulfate-reducing and methane-producing microbial consortia (Goffredi et al., 2008; Treude et al., 2009).

Chemosynthetic microorganisms found at deep water whale falls include free-living, sulfuroxidizing bacteria (e.g., Beggiatoa spp.) which cover the bones and the adjacent sediment surfaces, and symbiotic bacteria associated with bivalves and tube-worms (Bennett et al., 1994; Deming et al., 1997; Goffredi et al., 2004). Vesicomyid clams, bathymodioline mussels, and vestimentiferan tube-worms, together with their associated microbial consortia, constitute symbiont-dominated oases similar to those occurring at hydrocarbon seeps and hydrothermal vents (Dubilier et al., 2008).

Macrofaunal ecosystems around whale falls have been recognized in the fossil record as far back as the late Eocene (Kiel and Goedert, 2006); an age coincident with the evolution of the first large ocean-going whales (Kiel and Little, 2006). In the last two decades most of the studies were concentrated on the macrofaunal component of fossil whale fall communities, represented mainly by fossil chemosynthetic bivalves or bacterial mat-grazing gastropods found in close association with whale bones (Squires et al., 1991; Hachiya, 1992; Goedert et al., 1995; Amano and Little, 2005; Nesbitt, 2005; Kiel and Goedert, 2006; Amano et al., 2007; Pyenson and Haasl, 2007; 
has the attention focused on the traces left in the fossil record by the microbial component of whale fall communities, which are directly linked to the degradation of whale carcasses and on which is based the trophic pyramid at the climax of the ecological succession. Fossil biosignatures such as botryoidal cements, microbial peloids, authigenic pyrite and microborings were found in association with fossil whale bones (Amano and Little, 2005; Kiel, 2008; Shapiro and Spangler, 2009). Similar microbial features were observed also in Upper Cretaceus plesiosaurid bones, suggesting that communities similar to those of whale falls could have existed associated with carcasses of Mesozoic marine reptiles (Kaim et al., 2008). Most of the described bio-sedimentary fabrics are typical of other marine chemosynthetic environments like modern and fossil cold seep deposits, where they are interpreted as microbiologically induced mineralizations (for review see Peckmann and Thiel, 2004; Campbell, 2006; Barbieri and Cavalazzi, 2008). At seeps, consortia of anaerobic methane oxidizing archaea and sulfate reducing bacteria, as a consequence of their metabolism, bioinduce the precipitation of carbonate minerals within the sediments, thus favoring their accumulation as geological deposits. Shapiro and Spangler (2009) suggested that similarly at whale falls botryoidal cements, peloids and framboidal pyrite might precipitate as a consequence of microbial processes during the sulfophilic stage of the ecological succession. To the contrary, Kiel (2008) interpreted similar fabrics (e.g., clotted micrite) from late Eocene-early Oligocene whale falls and the surrounding carbonate concretions, like late diagenetic products formed when the bones were completely buried in sediment, and as a consequence not linked to the sulfophilic stage. In addition, microbial organisms such as algae, bacteria and fungi are known to play an important role in the degradation of apatite bones in marine settings (Jans, 2008). Microborings in fossil whale bones may have thus been originated by one of these trace makers (Amano and Little, 2005; Amano et al., 2007; Kiel, 2008; Shapiro and Spangler, 2009).

In their study, Shapiro and Spangler (2009), made a petrographic investigation of fossil whale bones from different depositional settings to verify whether the degree of whale bone 
degradation is controlled by environmental or depth-related factors. They reported the most convincing evidence of microbial degradation on whale bones from deep water whale falls and the lowest amount and fewest types of degradation on fossil bones from shallow marine depositional environments. Mid to shallow shelf fossil whale bones presented only traces of sulfide crystals and microborings, with no evidence of bacterial peloids and botryoids, the most convincing evidence of a sulfophilic stage according to their interpretation (Shapiro and Spangler, 2009). This result seems to reflect the picture coming from the study of the macro-invertebrate component of both modern and fossil whale falls: unlike their deep water counterpart, natural whale falls are rare on modern shelves, so that the course of the ecological succession is still poorly understood (see Smith, 2006). Some knowledge is gained from the fossil record, where chemosymbiotic bivalves associated with whale bones have been once documented in an outer shelf setting (Dominici et al., 2009; Danise et al., 2010). No chemosynthetic activity has been documented so far in shallow shelf and coastal settings. Shallow water whale falls may have played a role in the evolution and dispersal of macrofauna inhabiting modern deep sea chemosynthetic ecosystems. Molecular studies indicate that some specialized deep sea taxa from cold seeps and hydrothermal vents, like mytilid bivalves of subfamily Bathymodiolinae, evolved from shallow water ancestors living on organic falls (Distel et al., 2000; Jones et al., 2006; Duperon, 2010). In fact, despite the antiquity of chemosynthetic ecosystems, molecular clock calibrations infer a Cenozoic origin for most major clades inhabiting modern vents and seeps (Baco et al. 1999; Distel et al. 2000; Kano et al. 2002). Because of the lack of data on macro-invertebrates associated with shallow water whale falls, the study of microbial processes could help in the understanding of whale fall community development on the shelf. In this work we performed a detailed investigation on the fossil bones of a Miocene mysticete whale from shallow water -epineritic- sediments of Northern Italy. We looked for traces of microbial degradation of whale bone lipids with the aim of verifying if the processes described by Shapiro and Splanger (2009) for deep sea whale falls can be extended also to shallower settings 
and if the fossil biosignatures observed on the shelf are different from those of the deep sea. In addition to optical microscopy, a combination of analytical techniques, such as scanning electron microscopy, Raman spectroscopy and stable isotope geochemistry were applied for a detailed morphological and geochemical analysis of the studied fossil whale bones. The results allowed us to reconstruct taphonomic and diagentic processes related to the degradation of whale carcasses on the shelf and contribute novel data to the knowledge of the microbial signatures in fossil whale falls.

\section{Geological setting}

The fossil whale investigated in this paper, hereafter called "Voghera whale", was found in the lower member of the Monte Vallassa Formation, part of the Epiligurian succession cropping out in the northernmost part of the Northern Apennines, Italy (Fig. 1). The Monte Vallassa Formation ranges in age from the Serravallian to the Tortonian (13.8-7.2 Ma) and is an approximately $400 \mathrm{~m}$ thick sequence which registers a transgressive marine cycle spanning from coastal settings to inner and outer shelf deposits (Bellinzona et al., 1971). The lower member is characterized by blue-gray sandy marls rich in macro-invertebrates, like terebratulids among brachiopods, pectinids and ostreids among bivalves, gastropods, isolated corals and echinoids. The sediments are mostly homogenized, with the internal laminations obscured by bioturbation. Locally, hummocky cross stratification structures occur, indicating a storm-dominated shelf environment. Sedimentary data, together with the nature of the rich macrofauna, suggest an epineritic depositional environment, commonly defined as being $0-50 \mathrm{~m}$ depth (Veronesi, 1997). The lower member is assigned to the Serravallian (13.8-11.6 Ma) based on the occurrence of Uvigerina barbatula (Macfad), Stilotomella verneuili (D’Orb.), Orbulina universa (D’Orb.) and Globoquadrina dehiscens (Chap., Parr., Coll.) (Bellinzona et al., 1971).

\section{Materials and methods}



Northern Italy). The specimen (V658) was collected in 2007 at Cà del Monte, near to Cecima, Pavia

153

(Fig. 1), and consists of three vertebrae, a few ribs, one scapula and a number of undetermined fragments, enclosed in a carbonate concretion (Fig. 2A-B). The rest of the bones are still in situ waiting for further excavations. Fig. 2B shows how the vertebrae are still aligned, suggesting that the bones were subject to little or no reworking. Since a detailed morphological and taxonomical study of the specimen has not been undertaken yet, and is beyond the aims of the present work, it is not possible to provide information about its classification among mysticetes or its estimated body size.

Fragmentary bones partially enclosed in the carbonate concretion were selected for the analysis. They were firstly characterized by optical microscopy examination of covered and uncovered standard petrographic thin sections (30 $\mu \mathrm{m}$ thick) and polished surfaces. Optical analyses were performed in transmitted and reflected light using a Zeiss Axioplan2 Imaging microscope equipped with a Zeiss AxioCam digital camera and an Olympus BX51 TH-200 microscope equipped with an Olympus DP12 Digital Microscope Camera. Subsequently, the uncovered thin sections and polished surfaces were examined using a WITec Alpha500 AFM-confocal Raman microscope. Three objectives (Nikon 20x, 50x and 100x) and a frequency doubled Nd:YAG (532 nm) Ar-ion 20-mW monochromatic laser source were used to collect the Raman spectra. Beam centering and Raman spectra calibration were performed before spectra acquisition using a $\mathrm{Si}$ standard with a characteristic Si Raman peak at $520.4 \mathrm{~cm}^{-1}$. The optimum power for in situ analyses of different minerals was experimentally determined between 1.67 and $1.70 \mathrm{nW}$ at the sample surface for the different minerals phases. Raman spectra were recorded and treated using WITec Project 2.00® software, and calibrated after RRUFF-CrystalSleuth DataBase (Laetsch and Downs, 2006). Selected portions of the thin sections and freshly broken samples were etched in an aqueous solution of $1 \% \mathrm{HCl}$ between 5 and 120 seconds, air dried and Au-coated for scanning electron 
microscope observations and element analysis (SEM-EDX). SEM-EDX imaging and analyses were performed using a Field Emission Gun-SEM (FEG-SEM) Hitachi S4200 and a ZEISS EVO MA 15, both equipped with an X-ray energy dispersive spectrometer system. The operating conditions of the scanning electron microscopes were 5 to $20 \mathrm{keV}$ accelerating voltage for imaging, and 15-20 $\mathrm{keV}$ for elemental analyses.

${ }^{13} \mathrm{C}$ and ${ }^{18} \mathrm{O}$ stable isotope analyses were performed on carbonate cements inside the whale bones and on the external concretion. Samples (3-5 milligrams) were hand drilled from polished slabs. The powdered samples were dissolved in vacuum in $100 \%$ phosphoric acid at $25^{\circ} \mathrm{C}$, and analysed using a Finnigan-MAT 250 mass spectrometer. Reproducibility was checked by replicate analyses (10 identical samples) and the standard deviation was better than $\pm 0.3 \%$. All results are reported in per mil (\%) deviations from the V-PDB (Vienna-Pee Dee Belemnite) standard.

The instruments used are located at the Dipartimento di Scienze della Terra and Centro Interdipartimentale di Microscopia Elettronica e Microanalisi, Università di Firenze (Italy), at the Centre de Biophysique Moléculaire, CNRS, Orléans (France), at the Centre de Microscopie Electronique, Université d'Orléans (France), and at the Stable Isotope Laboratory, Department of Geology, Copenhagen University (Denmark).

\section{Results}

\subsection{Fossil bone preservation}

The Voghera whale bones are enclosed in a gray, fine-grained carbonate concretion, consisting of angular siliciclastic grains of quartz, feldspars and micas, and cemented with microcrystalline to small rhombohedral dolomite crystals (maximum size of the main axis $10 \mu \mathrm{m}$ ) (Fig. 3A). Poorly preserved bioclasts of benthic foraminiferal tests and concentrations of fecal pellets close to the fossil bones are also present (Fig. 3B). Fecal pellets are ovoid or elliptical shape, are up to $420 \mu \mathrm{m}$ in length and contain minor amounts of iron sulfide. 
The Voghera whale fossil bones are mineralized in carbonate-rich fluorapatite,

$\mathrm{Ca}_{5}\left(\mathrm{PO}_{4}, \mathrm{CO}_{3}\right)_{3} \mathrm{~F}$ (Fig. 4). They preserve both the compact and the cancellous bone tissue (Fig. 5A), are light brown in color in plane polarized and light-black to light-gray in cross polar, exhibiting a birefringence pattern (Figs. 5B,C). Vertebrate compact bones have a relatively solid and dense bone texture, whereas cancellous bones are spongy and highly porous and consist of plates and struts called trabeculae that, in life, are filled with marrow (sensu Lyman, 1994). In the Voghera whale, the external part of cancellous bones is highly enriched in dark iron sulfides (Fig. 5A). The original structure of the bones is well preserved: osteons, the major structural elements of bone tissue, and osteocytes, the bone cells, are clearly visible (Figs. 5B-D). As highlighted by the birefringence pattern in cross polars (Fig. 5B), osteons are made by a roughly cylindrical structure of successive concentric lamellae surrounding a centrally located Haversian canal, that in life contains blood vessel and nerves (Lyman, 1994). In the Voghera whale, osteons show a radial system of microcracks (Fig. 5C). Optical microscopy and Raman spectroscopy show reddish, globular aggregates of lepidocrocite, $\gamma-\mathrm{FeO}(\mathrm{OH})$, intimately associated with the tissue of compact and cancellous bones (Fig. 5E). The lepidocrocite grains have a diameter in between 4 and $8 \mu \mathrm{m}$, however, rare larger diameter grains up to $40 \mu \mathrm{m}$ were also observed.

\subsection{Carbonate cements filling cancellous bones}

Cancellous bones are filled with different carbonate phases, which include microcrystalline dolomite, rhombohedral dolomite and euhedral (sparry) calcite (Fig. 6). In thin section, microcrystalline dolomite exhibits a clotted texture, forming dark and cloudy aggregates (Fig. 6A). Locally it forms well organized rounded to sub-rounded peloids with an average radius of $57 \mu \mathrm{m}$ (min $37.8 \mu \mathrm{m}$, max $116 \mu \mathrm{m}$ ) (Figs. 6B-D). Micropeloids show a characteristic internal organization: the inner part consists of a dense aggregate of microcrystalline dolomite, whereas the external portion shows a characteristic rim of rhombohedral dolomite crystals (Fig. 6C). SEM observations 
of the micropeloids highlights a dense nucleus of microcrystalline dolomite, 3 to $5 \mu \mathrm{m}$ in size, and an external rim of rhombohedral dolomite with an average main axis size of $22 \mu \mathrm{m}$ (Figs 6E).

Similar dolomite rhombohedra also line the trabecular bone surface (Fig. 6A,D). Locally, dolomite rhombohedral crystals exhibit a particular habit of small aggregates with a rosette-like form and an average radius of $20 \mu \mathrm{m}$ (Fig. 7). They can be solitary or coalescent (2-4 bodies), and they are especially common close to bone trabeculae, embedded in the sparry calcite (Fig. 7A). All these rosette-like structures are characterized by a dark, opaque nucleus of a few pyrite framboids surrounded by dolomite rhombohedra (Fig. 7B). Raman analyses performed on the micropeloids and on the rosette-like structures show the presence of disordered carbonaceous matter (DCM) associated with the dolomite crystals and the pyrite framboids, respectively (Fig. 8A-B). Pyrite framboids, commonly associated with the micropeloids and the rosette-like structures, have an average diameter of $6 \mu \mathrm{m}$ and can be partially or totally oxidized to lepidocrocite (Fig. 8B). SEMEDX observations show that pyrite framboids can be zoned, with a pyritic internal nucleus (Fe, S) and an external thin rim of lepidocrocite (Fe, O) (Fig. 6F).

\subsection{Microborings}

Two different microboring morphologies were observed in the Voghera whale samples (Figs 9-11). The first, called Type 1, is the more abundant and occurs both in the inner cancellous bone and in the outer compact bone (Fig. 9). Type 1 microborings have an average diameter of $3.8 \mu \mathrm{m}$ (observed diameters between 1.7 and $8.4 \mu \mathrm{m}$ ) and their maximum measured length is $37 \mu \mathrm{m}$. Optical microscope observations of Type 1 microborings show that they are made by nonbifurcating, slightly curved microtunnels without any preferred orientation (Figs. 9B,D). SEM-EDX analyses show that the wall surface of the microtunnels is intensely encrusted by micron-sized ironoxides (Figs. 11B-C). On the external part of compact bones Type 1 microborings form a densely tunneled zone which is about $300 \mu \mathrm{m}$ thick (Figs. 9C-D, 11A). The bioeroded area is delimited by 
bright cement lines that mark the boundaries between the secondary osteons of the Haversian systems, whereas the concentric lamellae typical of compact bone osteons are totally obliterated by the intense bioerosion (Figs 9C-D).

Type 2 microborings are less abundant than Type 1 and occur exclusively on the external part of compact bones (Fig. 10). They have an average diameter of $2.3 \mu \mathrm{m}$ (observed diameter between $1.3 \mu \mathrm{m}$ and $3.7 \mu \mathrm{m}$ ) and their maximum measured length is $81 \mu \mathrm{m}$. They are straight or slightly curved tunnels, often branching with $90^{\circ}$ bifurcations (Figs. 10A,D). Some of them exhibit central swellings that can be partially filled by pyrite-lepidocrocite framboids (Fig. 10B). Some filaments reveal internal segmentation (Fig. 10C), and terminal, sack-shaped swellings, 15-20 $\mu \mathrm{m}$ wide, can occur at the tip of some filaments (Fig. 10B). Sometimes microtunnels can be linked to the bone surface by larger apertures (Fig. 10D). Neither Type 1 nor Type 2 microboring development is observed around post-mineralized fractures.

In the same area in which the microborings occur, a $30 \mu \mathrm{m}$ thick barite coating encrusts the external surface of compact bones (Fig. 11D). SEM-EDX observations indicate that the barite crust has a microcrystalline habit and is associated with a Sr-rich calcite cement (Figs. 11E-F).

\subsection{Stable isotope analyses}

Carbon and oxygen stable isotope values were obtained from the different carbonate mineral phases within our samples: 1) the dolomite cement of the enclosing concretion, 2) the clotted dolomite and the micropeloids totally or partially occluding voids inside the bones, and 3) the Cacarbonate, sparry calcite cements found inside and outside the bones (Fig. 12). The dolomite cements of the enclosing concretion have $\delta^{13} \mathrm{C}$ values as low as $-7.34 \%$ and $\delta^{18} \mathrm{O}$ values ranging from +3.86 to $+4.36 \%$. The $\delta^{13} \mathrm{C}$ and $\delta^{18} \mathrm{O}$ values of the microcrystalline dolomite sampled inside bone trabeculae, range from -7.28 to $-7.15 \%$, and from +3.51 to $+3.54 \%$ respectively. The sparry 

values ranging between -1.67 and $-0.3 \%$.

\section{Discussion}

\subsection{Early stages of bone degradation}

calcite occluding voids in- and outside bones has $\delta^{13} \mathrm{C}$ values between -1.33 and $+0.22 \%$, with $\delta^{18} \mathrm{O}$

The Voghera whale fossil bones are preserved in Ca-rich fluorapatite (Fig. 4), the mineral into which (hydroxyapatite) bones are commonly transformed during diagenesis (Allison and Briggs, 1991). The birefringent pattern of the investigated fossil bones suggests that the bones retain the original alignment of apatite crystals. This pattern is typical of fresh, proteinated bones, despite the loss of the collagen fibers due to fossilization (Hubert et al., 1996). The presence of iron sulfides (pyrite) within the bone matrix may be related to the early stages of bacterial bone decay. Sulfide produced by the bacterial degradation of bone collagen could have induced iron sulfide precipitation inside small void spaces within the bones, such as canaliculi, that are no longer visible because they have been occluded by diagenesis (Pfretzschner, 2001). Similar monosulfide concentrations have also been observed to form layers and infill in the vertebra micropores of modern deep-water whale falls (see Fig. 5 in Allison et al., 1991). In addition, the development of radial microcracks in compact bones could be related to the degradation of collagen during early diagenetic processes as a consequence of the hydration of gelatinized collagen that swelled the bones (Pfretzschner, 2004). Microcracks are considered to enhance the exchange of fluids and chemicals between the bones and the surrounding water during bone decay (Pfretzschner, 2004).

The degradation of bone collagen favored the diffusion of oxygen and sulfates from the surrounding water into the Voghera whale bones, which in turn facilitated the onset of decay in the inner part of the bones, where whales host large amounts of lipids. Then, once oxygen was depleted by aerobic heterotrophic bacteria, sulfate reduction and methanogenesis could start (see Allison et al., 1991). The concentric zone enriched in iron sulfides observed in the outer part of the Voghera cancellous 
bones may represent the boundary between an internal region in which sulfate reduction took place at the lipid-water interface and an outer zone where sulfide oxidation and aerobic decay were the dominant processes. A similar distribution of iron sulfides inside whale bones has also been recognized in modern and fossil deep water whale falls (Allison et al., 1991; Shapiro and Spangler, 2009).

\subsection{The origin of microborings}

Microborings in the Voghera fossil whale bones were generated prior to the fracturing and mineralization of the bones as they are not concentrated around post-mineralized fractures (Trueman and Martill, 2002). Type 1 microborings are in the same range size of those described in previous studies on deep-water fossil whale-falls (Amano and Little, 2005; Kiel, 2008; Shapiro and Spangler, 2009), plesiosaurid carcasses (Kaim et al., 2008) and in some samples from shallow shelf settings analyzed by Shapiro and Spangler (2009). Type 2 microborings are smaller and similar features have not been described before from fossil whale falls.

In previous studies on fossil whale falls, microborings have been assigned to the action of bacteria, algae or fungi, but a more precise determination was not attempted (e.g., Amano and Little, 2005; Kiel, 2008; Shapiro and Spangler, 2009). Although similar microborings have been recognized in modern whale falls (Allison et al., 1991), they have never been studied in detail, and the associated organisms and their metabolism are still unknown. The recent description of the traces left by the bone eating worms Osedax, both in modern and fossil whale bones (Higgs et al., 2010; Kiel et al., 2010; Higgs et al., 2011), excludes the possibility that microborings were made by siboglinid worms. Osedax traces are one order of magnitude larger than the Voghera whale microborings, and show a very different pattern of destruction of the bones. The morphologies of the studied microborings are similar to the traces left by euendoliths, endolithic microorganisms that actively penetrate into rocks or hard substrates and create microtubular cavities conforming to the 
shapes of their bodies (Golubic et al., 1981; McLoughlin et al., 2007). In the marine ecosystem such organisms mainly include phototrophic cyanobacteria and algae and heterotrophic fungi and bacteria, all of which are capable of metabolizing collagen and dissolving the mineral matrix (e.g., Davis, 1997; Trueman and Martill, 2002). While phototrophic euendoliths dominate within the sunlight-illuminated (euphotic) coastal zones in the oceans, the light-independent heterotrophs follow the distribution of organic substrates for food and are found in all depths ranging from shallow coastal waters to the abyssal depths (Golubic et al., 2005 and references therein). As a consequence of convergent evolution of boring and reproductive behavior among unrelated organisms that exploit similar environments in shallow waters, the distinction between the borings of endolithic fungi, filamentous (and sometimes coccoid) cyanobacteria and eukaryotic algae is often difficult (Golubic et al., 2005; Jans, 2008).

The occurrence of the Voghera Type 1 microborings along the internal walls of cancellous bones (Fig. 9A) that is, in an environment not influenced by sunlight, suggests that the responsible organisms are heterotrophic rather than phototrophic. In addition, the absence of bifurcations, the presence of permineralized rims around the borings, and the destructive pattern of the bones support their prokaryotic origin (Turner-Walker, 2008; Turner-Walker et al., 2002; Jans, 2008). Type 2 microborings instead only occur on the external part of the bones (Fig. 10). Here, the presence of dichotomously branched ramifications with internal segmentation and, bag-shaped swellings supports a fungal origin (Schumann et al., 2004; Golubic et al., 2005). According to previous literature on microbial bioerosion of vertebrate fossil bones, Type 1 microborings can be defined as linear longitudinal tunnels and Type 2 microborings as Wedl tunnels (Hacket, 1981; Davis, 1997; Jans, 2008).

\subsection{A possible origin of the microcrystalline barite}


Microcrystalline barite $\left(\mathrm{BaSO}_{4}\right)$ was detected on the external surface of the fossil bones (Fig. 11). Barite is known to form in numerous microbially colonized habitats, including marine cold seeps, white smokers, hot springs, and the upper water columns of lakes and oceans (Bonny and Jones, 2008 and references therein). Barite deposits generally form as a result of mixing of soluble bariumcontaining fluids with sulfate-rich fluids. Deposits formed by direct precipitation from bariumenriched hydrothermal fluids are known as hydrothermal barite. They are restricted to the vicinity of seafloor vents and are commonly associated with anhydrite and sulfides (e.g., Koski et al., 1985). At cold seeps barite precipitation occurs when rising barium-rich fluids derived from the dissolution of biogenic barite deposits react with sulfate-rich, downwards-diffusing seawater or ascending brines (Torres et al., 2003; Aloisi et al., 2004). In the water column, barium sulfate is known to precipitate within microenvironments of decaying planktonic organisms, which may actively or passively accumulate barium and form barite in pelagic sediments underlying high productivity waters (Dehairs et al., 1980; Bishop, 1988; Paytan and Griffith, 2007). Authigenic barite has also been documented in biogenic calcareous rocks where barium is derived from the decomposition of organic matter, plankton and other organisms such as bacteria (Stamatakis and Hein, 1993). Although the morphologies and sizes of marine barite crystals in the water column and in marine sediments indicate a possible biogenic origin, the living organisms which directly precipitate barite have not yet been identified in seawater (González-Munõz et al., 2003). However barite precipitation by living organisms (protozoa) has been observed in lacustrine freshwater environments, where sulfur-metabolizing microbes are able to control and mediate barite saturation (e.g., González-Munõz et al., 2003; Senko et al., 2004). Whale bones can be a good source of barium, thanks to the high concentrations of organic matter, including collagen and lipids. Microcrystalline barite on the external surface of the Voghera fossil whale can have biogenically precipitated around the decaying bones shortly after burial, as in previous reports (Stamatakis and Hein, 1993). 


\subsection{The origin of carbonate cements inside and around the bones}

The clotted textures and micropeloidal fabrics in the Voghera fossil whale bones, characterized by richness of dark organic matter, indistinct margins, cloudy interiors, and sulfide minerals (Fig. 6), are similar to those described in a wide variety of different geological settings such as shallow water carbonates and microbialites, coral reef crusts and mud mounds, methane seeps, hot springs and carbonate-rich soils (see Flügel, 2010 for a review). They are the most common microbially induced structures in carbonate rocks and they typically consist of sphericalto-elliptical microscopic aggregates of microcrystalline clots or peloids (e.g., calcite, aragonite), cemented by carbonate and/or sediments (Chafetz, 1986; Burne and Moore, 1987; Shapiro, 2004). The clotted texture is related to small-scale variations in the chemical microenvironment during carbonate precipitation caused by the metabolic activities of microorganisms (Burne and Moore, 1987), whereas the peloids are interpreted as microbial bio-products or biominerals that are thought to be precipitated on the surface of bacterial clumps (Chafetz, 1986). Clotted fabrics and micropeloids were recognized also in some of the deep water whale falls investigated by Shapiro and Spangler (2009) and interpreted as biogenic in origin.

Our data expand the environmental settings in which similar biosignatures can be found associated with whale bones and clearly confirm that the same model presented by Riding and Tomàs (2006) for the calcification of bacterial micropeloids in Cretaceous stromatolites can also be applicable to fossil whale bones. According to this model the clotted microcrystalline dolomite and the micropeloids of the Voghera whale would represent the products of organic matter decay immediately below the sediment-water interface. During early diagenesis, microbial decay of whale bone lipids induced dolomite precipitation, which in turn induced the calcification of bacterial aggregates forming the nuclei of micropeloids. The spatial distribution of the aggregating bacterial colonies determined the spacing of the micropeloidal masses. When all the lipids were consumed 
and the peloids overgrew, the sparry calcite cement occluded the water-filled voids. The peculiar architecture of rosette-like structures in Fig. 7 (spheroidal dolomitic body generated around an opaque nucleus of few pyrite framboids) is reminiscent of small peloids, although they lack the inner filling of microcrystalline dolomite. They could also represent bacterially induced precipitates overgrown by single euhedral dolomite crystals instead of being completely lithified by microcrystalline dolomite, as supposed for similar dolomite aggregates from a Miocene methane seep of northern Italy (Cavagna et al., 1999).

A biogenic origin of the rosette-like structures and the micropeloids as well is further supported by the presence of disordered carbonaceous matter as detected by Raman microscopy. The first order $\mathrm{G}\left(\sim 1350 \mathrm{~cm}^{-1}\right)$ and $\mathrm{D}\left(\sim 1360 \mathrm{~cm}^{-1}\right)$ bands of carbonaceous matter were observed in close association with both of them (Fig. 8). G and D bands of the Raman spectra represent a mixture of crystalline (G: graphite) and poorly organized (D: disordered) carbonaceous material, respectively (e.g., Jehlička and Bény, 1992; Pasteris and Wopenka, 2003). The Raman analytical technique, recently introduced to paleontology (e.g., Kudryavtsev et al., 2001), is widely used for the in situ identification of minerals and their molecular-structural study, and to document the molecular structure and geochemical maturity of organic carbonaceous matter, e.g. graphite and graphite-like carbonaceous mineraloids (Jehlička and Bény, 1992; Pasteris and Wopenka, 2003; Marshall et al., 2010). Although the presence of disordered carbonaceous matter in association with the Voghera whale micropeloids and the rosette-like structures alone is not an unequivocal proof of their biologic origin, it represents a further clue supporting their biogenicity if put together with all the other evidences discussed (biosignature suite sensu Boston et al., 2001)

The precipitation of dolomite in the micropeloids of the Voghera fossil whale bones was probably determined by the local chemistry of the pore waters. Dolomite precipitation, in fact, is known to be inhibited by normal marine sulfate concentration, whereas it is favored when sulfates are removed from the pore waters by an intense reducing bacterial activity (Kastner, 1984). In 
particular, the degradation of organic matter by sulfate reducing bacteria can promote early dolomite precipitation by simultaneously increasing the carbonate alkalinity and reducing near zero the sulfate ion concentration (Compton, 1988). The sediment depth of early dolomite precipitation depends on the organic input, the rate of sulfate reduction and sedimentation rate, and can begin at less than $1 \mathrm{~m}$ below the sediment sea-water interface (Mazzullo, 2000). An intense sulfate reduction is furthermore suggested by the common co-occurrence in the Voghera samples of pyrite framboids associated with the dolomitic clots and the rhombohedric dolomite cements. Microbially produced pyrite framboids and crystals are common in sedimentary rocks, especially in fine-grained lithologies (e.g., Berner, 1970). However the association of framboidal pyrite with authigenic carbonates is less common, and in seep-related authigenic carbonates it is considered to be a paleoenvironmental indicator for bacteria sulfate reduction independent of burial diagenesis (Cavagna et al., 1999; Shapiro, 2004; Cavalazzi et al., 2011).

The presence of iron oxide-hydroxides (lepidocrocite) associated with iron sulfides suggests a partial oxidative diagenetic transformation of the original pyrite (Bailey et al., 2010; Cavalazzi et al, 2011). Iron oxides and oxide-hydroxides are common in fossil bones (Wings, 2004) and they can originate during late diagenetic processes when external oxidants enter the fossil bones and transform the existing minerals (Pfretzschner, 2001). Pyrite framboids surrounded by a thin rim of lepidocrocite, as those observed at Voghera, resemble the structures described from a Pleistocene methane seep in California where iron oxides and oxide-hydroxides (e.g., hematite, goethite) in association with authigenic sulfides precipitated as a consequence of the anaerobic oxidation of methane and bacterial sulfate reduction (Bailey et al., 2010). Here the diagenetic oxidation of reduced minerals was interpreted as the transition from sulfidic, anoxic conditions, to welloxygenated conditions after the cessation of the seep activity (Bailey et al., 2010). Similarly the oxidation of the pyrite framboids of the Voghera whale may have occurred during the late 
diagenetic history of the bones once the whale bone lipids were consumed and sulfate reduction processes ceased.

\subsection{Carbon and oxygen stable isotope signatures}

Carbonate minerals derived from the microbial oxidation of organic matter are characterized by distinctive carbon and oxygen stable isotope signatures which can help the understanding of the processes involved in their precipitation. In particular, sedimentary organic carbon is depleted in ${ }^{13} \mathrm{C}(\sim-25 \%)$ relative to seawater $\left(\delta^{13} \mathrm{C} \sim 0 \%\right)$, and carbonate derived from degradation of organic matter inherits the carbon isotope composition of its precursor (Coleman et al., 1993). The oxygen isotopic composition is thought to be mainly determined by the temperature of carbonate precipitation, ${ }^{18} \mathrm{O}$-enriched isotopic composition can be related to low bottom water temperatures in marine shelf environments, whereas more ${ }^{18} \mathrm{O}$-depleted values are most likely the result of continued precipitation at higher temperatures associated with greater burial depth (Mozley and Burns, 1993).

The depleted $\delta^{13} \mathrm{C}$ values of the Voghera whale microcrystalline dolomite sampled inside bone trabeculae, as low as $-7.28 \%$, suggest that the dolomite precipitation was driven by sulfate reduction processes during the bacterial oxidation of organic matter. However, the difference compared to theoretical values implies the mixing with a carbonate source of marine origin (Raiswell and Fisher, 2000). The measured values of $\delta^{13} \mathrm{C}$ could have also been affected by sampling methods. Because microcrystalline dolomite and sparry calcite occur on very small spatial scale, their sampling with a hand held micro-drill could have caused contamination between neighboring carbonate phases. As a consequence, it could have produced more enriched $\delta^{13} \mathrm{C}$ values for the microcrystalline dolomite. The similar carbon and oxygen isotopic signal obtained both for the dolomite intimately associated with cancellous bones and for the dolomite in the enclosing concretion suggests that they precipitated in similar geochemical conditions. The slightly high $\delta^{18} \mathrm{O}$ 
values for the dolomite cements inside and outside the bones are indicative of low bottom water temperatures on the shelf and low late-diagenetic alteration (Mozley and Burns, 1993). Finally the carbon and oxygen stable isotope values of the sparry calcite cement inside and outside the bones (avg $\delta^{13} \mathrm{C}:-0.55 \%$; avg $\delta^{18} \mathrm{O}:-0.98 \%$ ) are consistent with a (late) precipitation in chemical equilibrium with seawater (Mozley and Burns, 1993). Isotope data of the two main carbonate phases, together with their spatial distribution, structures and mineralogy described and previously discussed, are consistent with the hypothesis that dolomite cements are of microbial origin and precipitated early during the sediment's story. To the contrary sparry calcite originated during late diagenetic processes. As observed by Kiel (2008), who analyzed enclosing concretions and cements from inside the bones of late Eocene-early Oligocene deep water whale-falls of the Lincoln Creek Formation (Washington State, USA), the carbonate concretion formed after that the bones were buried in the sediments.

\subsection{Taphonomic model: a hypothesis}

All the collected data interpreted following previous studies on modern and fossil whale falls and on similar reduced environments like methane seeps, allow us to reconstruct the possible taphonomic history of the Voghera fossil whale. Although shark teeth were not found associated with the fossil bones, which would be a direct clue for scavenging, we assume that once the carcass arrived to the sea floor soft, fleshy tissues were rapidly removed by mobile scavengers to prevent the carcass refloating after production of decay gasses. In fact, in contrast to deep sea settings where hydrostatic pressure limits the generation of buoyant decompositional gases, at shallow depths $(<$ $1000 \mathrm{~m}$ ) gas generation will tend to refloat whale carcasses unless gas generation is hindered (see Schäfer, 1972; Allison et al., 1991). The decay of the bone organic matter started with the bacterial degradation of bone collagen, as testified by the precipitation of iron sulfides in the bone matrix and by radial micro-cracks in compact bones. Saprophagous bone borers, probably feeding on bone 
collagen, created microscopic tunnels in the external surface of the bones, migrating progressively inward. All these processes enhanced the inflow of seawater inside the bones, allowing the diffusion of sulfate. After the consumption of free oxygen by aerobic heterotrophic bacteria, the decay of bone lipids in the marrow cavities of cancellous bones was facilitated by anaerobic sulfate reduction. Microbial sulfide production induced the precipitation of iron sulfides in the external area of trabecular bones. Notwithstanding the occurrence of iron sulfides suggests the presence of elevated $\mathrm{H}_{2} \mathrm{~S}$ concentrations within the whale bones, no macrofauna indicative of the onset of a sulfophilic stage of the ecological succession, nor fossil traces of sulfur oxidizing bacteria, were found associated with the Voghera whale. It is hypothesized that the carcass was buried before all the whale bone lipids were consumed, and that sulfate reduction processes promoted the precipitation of microcrystalline- and euhedral-dolomite cements both inside bone trabeculae and in nearby sediments. A carbonate concretion formed around the whale bones. Whale organic matter decay favored the contemporaneous accumulation of barium and the consequent precipitation of microcrystalline barite on the surface of the bones. When all bone lipids were consumed, microbial dolomite precipitation ceased and sparry calcite precipitation in equilibrium with sea water occluded the remaining voids of trabecular bones. Finally, during late diagenetic processes, external oxidants induced the partial oxidation of pyrite into iron oxide-hydroxides. It is difficult to estimate how long the carcass remained on the sea floor before burial. In an epineritic, storm-dominated environment like the lower member of the Monte Vallassa formation, a single storm event may have sufficed to bury the carcass. The study of lower Jurassic ammoniteferous concretions with microbial fabrics and cements similar to those observed at Voghera, indicates that instantaneous depositional events favor the onset of early diagenetic processes and the associated intense microbial activity (Curtis et al., 2000).

\section{Conclusions}


The detailed microfacies and geochemical analyses of Miocene fossil whale bones

524 (Serravallian, Voghera, northern Italy) allowed us to reconstruct the main thaphonomic and diagenetic events related to the decay of a whale carcass in a shallow water, epineritic environment. Multiple evidences of microbial processes linked to the carcass degradation were detected, related to both pre- and post-burial phases.

The analysis of microborings allowed us to restrict the range of possible trace makers. In particular, traces were left by two different types of euendolith microorganisms, a prokaryote and a fungus. They probably fed on the whale bone collagen, and participated to the decay of the bones when they were still exposed on the sea floor. Future analyses on similar organisms living at modern whale falls may help a better understanding of their metabolism and trophic role.

Evidence of pre-burial sulfate reduction processes and hydrogen sulfide emission around the bones is scanty and no decisive. The most convincing evidence is the presence of a concentric zone enriched in iron sulfides in the outer part of cancellous bones, representing the boundary between an internal region of sulfate reduction at the lipid-water interface and an outer zone of sulfide oxidation. These structures are also observed in modern whale falls. All the other microbiallymediated biofabric and biominerals observed in the bones and in the enclosing concretion testify for post-burial anaerobic decay of bone lipids by sulfate reduction. Microbial peloids, rosette-like structures, clotted textures and microcrystalline barite formed during early diagenetic processes. Iron sulfides are thus the only evidence of the possible onset of a sulfophilic stage of the ecological succession before the bones were buried below sediments. The occurrence of clotted textures and micropeloids associated with whale bones cannot be used alone as a fossil evidence of the development of a whale fall sulfophilic stage. The same fabrics can in fact form after and in the absence of a whale fall community as currently understood. 
The present conclusions confirm that the occurrence of the hard parts of chemosynthetic

547 invertebrates associated with fossil whale bones is still the more convincing evidence of the

548 development of a sulfide-base chemoautotrophic ecosystem.

\section{Acknowledgements}

The authors thank Birger Schmitz for the isotope analyses, Annie Richard and Maurizio

\section{References}

Allison, P.A., Briggs, D.E.G., 1991. The taphonomy of soft-bodied animals, in: Donovan, S.K. (Ed.), Fossilization: the process of taphonomy. Belhaven Press, London, pp. 120-140.

Allison, P.A., Smith, C.R., Kukert, H., Deming, J.W., Bennett, B.A., 1991. Deep-water taphonomy of vertebrate carcasses: a whale skeleton in the bathyal Santa Catalina Basin. Paleobiology 17, 78-89.

Aloisi, G., Wallmann, K., Bollwerk, S.M., Derkachev, A., Bohrmann, G., Suess, E., 2004. The effect of dissolved barium on biogeochemical processes at cold seeps. Geochimica et Cosmochimica Acta 68, 1735-1748.

Amano, K., Little, C.T.S., 2005. Miocene whale-fall community from Hokkaido, northern Japan. Palaeogeography, Palaeoclimatology, Palaeoecology 215, 345-356. 
Amano, K., Little, C.T.S., Inoue, K., 2007. A new Miocene whale-fall community from Japan.

Palaeogeography, Palaeoclimatology, Palaeoecology 247, 236-242.

Baco, A.R., Smith, C.R., Peek, A.S., Roderick, G.K., Vrijenhoek, R.C., 1999. The phylogenetic relationships of whalefall vesicomyid clams based on mitochondrial COI DNA sequences. Marine Ecology Progress Series 182:137-147.

Bailey, J.V., Raub, T.D., Meckler, A.N., Harrison, B.K., Raub, T.M.D., Green, A.M., Orphan, V.J., 2010. Pseudofossils in relict methane seep carbonates resemble endemic microbial consortia. Palaeogeography, Palaeoclimatology, Palaeoecology 285, 131-142.

Barbieri, R., Cavalazzi, B., 2008. Fossil microorganisms at methane seeps: an astrobiological perspective, in: Seckbach, J., Walsh, M. (Eds.), From Fossils to Astrobiology. Records of Life on Earth and the search for Extraterrestrial Biosignatures Series: Cellular Origin, Life in Extreme Habitats and Astrobiology. Springer-Verlag, pp. 297-318.

Bellinzona, G., Boni, A., Braga, G., Marchetti, G., 1971. Note illustrative della Carta Geologica d'Italia in scala 1:100.000, Foglio 71, Voghera. Servizio Geologico d'Italia, Roma, pp. 121.

Bennett, B.A., Smith, C.R., Glaser, B., Maybaum, H.L., 1994. Faunal community structure of a chemoautotrophic assemblage on whale bones in the deep northeast Pacific Ocean. Marine Ecology Progress Series 108, 205-223.

Berner, R.A., 1970. Sedimentary pyrite formation. American Journal of Science 268, 1-23.

Bishop, J.K.B., 1988. The barite-opal-organic carbon association in oceanic particulate matter. Nature 332, 341-343.

Bonny S.M., Jones, B., 2008. Experimental precipitation of barite $\left(\mathrm{BaSO}_{4}\right)$ among streamers of sulfur-oxidizing bacteria. Journal of Sedimentary Research 78, 357-365.

Boston, P.J., Spilde, M.N., Northup, D.E., Melim, L.A., Soroka, D.A., Kleina, L.G., Lavoie, K.H., Hose, L.D., Mallory, L.M., Dahm, C.N., Crossey, L.J., Scheble, R.T., 2001. Cave biosignature suites: Microbes, minerals and Mars. Astrobiology 1, 25-55. 
Burne, R.V., Moore, L.S., 1987. Microbialites: organosedimentary deposits of benthic microbial

597

598

599

600

601

602

603

604

605

606

607

608

609

610 communities. Palaios 2, 241-254.

Campbell, K.A., 2006. Hydrocarbon seep and hydrothermal vent paleoenvironments: past developments and future research directions. Palaeogeography, Palaeoclimatology, Palaeoecology 232, 362-407.

Cavagna, S., Clari, P., Martire, L., 1999. The role of bacteria in the formation of cold seep carbonates: geological evidence from Monferrato (Tertiary NW Italy). Sedimentary Geology 126, 253-270.

Cavalazzi, B., Barbieri, R., Cady, S.L., George, A.D., Gennaro, S., Westall, F., Lui, A., Canteri, R., Rossi, A.P., Ori, G.G., Taj-Eddine, K., 2011. Iron-rich framboids from a hydrocarbon-related Devonian mound (Anti-Atlas, Morocco) as pseudofossils of fossil bacterial colonies. Sedimentary Geology, doi:10.1016/j.sedgeo.2011.09.007

Chafetz, H.S., 1986. Marine peloids; a product of bacterially induced precipitation of calcite. Journal of Sedimentary Research 56, 812-817.

Clari, P., Dela Pierre F., Martire L., Cavagna S., 2009. The Cenozoic CH4-derived carbonates of Monferrato (NW Italy): A solid evidence of fluid circulation in the sedimentary column. Marine Geology 265, 167-184.

Coleman, M.L., Raiswell, R., Brown, A., Curtis, C.D., Aplin, A.C., Ortoleva, P.J.,

Gruszczynski, M., Lyons, T., Lovley, D.R., Eglinton, G., 1993. Microbial mineralization of organic matter: mechanisms of self-organization and inferred rates of precipitation of diagenetic minerals. Philosophical Transactions: Physical Sciences and Engineering 344, 69-87.

$$
\text { Compton, J.S., 1988. Degree of supersaturation and precipitation of organogenic dolomite. }
$$

Geology 16, 318-321.

Curtis, C.D., Cope, J.C.W., Plant, D., Macquaker, J.H.S., 2000. 'Instantaneous' sedimentation, early microbial sediment strengthening and a lengthy record of chemical diagenesis preserved in 
Lower Jurassic ammonitiferous concretions from Dorset. Journal of the Geological Society 157, $165-172$.

Danise, S., Dominici, S., Betocchi, U., 2010. Mollusk species at a Pliocene shelf whale fall (Orciano Pisano, Tuscany). Palaios 25, 449-556.

Davis, P.G., 1997. The bioerosion of bird bones, International Journal of Osteoarchaeology 7, $388-401$.

Dehairs, F., Chesselet, R., Jedwab, J., 1980. Discrete suspended particles of barite and the barium cycle in the open Ocean. Earth and Planetary Science Letters 49, 528-550.

Deming, J.W., Reysenbach, A.L., Macko, S.A., Smith, C.R., 1997. Evidence for the microbial basis of a chemoautotrophic invertebrate community at a whale fall on the deep seafloor: bonecolonizing bacteria and invertebrate endosymbionts. Microscopy Research and Technique 37, 162 170.

Distel, D.L., Baco, A.R., Chuang, E., Morrill, W., Cavanough, C., Smith, C.R., 2000. Do mussels take wooden steps to deep-sea vents? Nature 403, 725-726.

Dominici, S., Cioppi, E., Danise, S., Betocchi, U., Gallai, G., Tangocci, F., Valleri, G., Monechi, S., 2009. Mediterranean fossil whale falls and the adaptation of mollusks to extreme habitats. Geology 37, 815-818.

Dubilier, N., Bergin, C., Lott, C., 2008. Symbiotic diversity in marine animals: the art of harnessing chemosynthesis. Nature Reviews 6, 725-740.

Duperon, S., 2010. The diversity of deep-sea mussels and their bacterial symbioses, in: Kiel S. (Ed.), The Vent and Seep Biota: Aspects from Microbes to Ecosystems. Springer, pp. 137-168. Flügel, E., 2010. Microfacies of carbonate rocks, second ed. Springer, Berlin. Goedert, J.L., Squires, R.L., Barnes, L.G., 1995. Paleoecology of whale-fall habitats from deepwater Oligocene rocks, Olympic Peninsula, Washington state. Palaeogeography, Palaeoclimatology, Palaeoecology 118, 151-158. 
Goffredi, S.K., Paull, C.K., Fulton-Bennett, K., Hurtado L.A., Vrijenhoek, R.C., 2004. Unusual

647

648

649

650

651

652

653

654

655

656

657

658

659

660

661

662

663

664

665 benthic fauna associated with a whale fall in Monterey Canyon, California. Deep-Sea Research I $51,1295-1306$.

Goffredi, S.K., Wilpiszeski, R., Lee, R., Orphan, V.J., 2008. Temporal evolution of methane cycling and phylogenetic diversity of archaea in sediments from a deep-sea whale-fall in Monterey Canyon, California. The International Society for Microbial Ecology Journal 2, 204-220.

Golubic, S., Friedmann, I., Schneider, J., 1981. The lithobiontic ecological niche, with special reference to microorganisms. Journal of Sedimentary Petrology 51, 475-478.

Golubic, S., Radtke, G., Le Campion-Alsumard,T., 2005. Endolithic fungi in marine ecosystems. Trends in Microbiology 13, 229-235.

Gonzaléz-Munoz, M.T., Fernández-Luque, B., Martínez-Ruiz, F., Chekroun, K.B., Arias, J.M., Rodríguez-Gallego, M., Martínez-Canamero, M., De Linares, C., Paytan, A., 2003. Precipitation of Barite by Myxococcus xanthus: Possible implications for the biogeochemical cycle of Barium. Applied and Environmental Microbiology 69, 5722-5725.

Hachiya, K., 1992. A unique community in the reduced environment found from the Morozaki Group. Kaseki no Tomo (Pubblication of the Tokai Fossil Society) 39, 37-41.

Hackett, C.J., 1981. Microscopical focal destruction (tunnels) in exhumed human bones. Medicine, Science and the Law, 21: 243-265.

Higgs, N.D., Glover, A.G., Dahlgren, T.G., Little, C.T.S., 2010. Using computed-tomography to document borings by Osedax mucofloris in whale bone. Cahiers de Marine Biologie 51, 401-405. Higgs, N.D., Little, C.T.S., Glover, A.G., Dahlgren, T.G., Smith, C.R., Dominici S., 2011. Evidence of Osedax worm borings in Pliocene ( $\sim 3 \mathrm{Ma})$ whale bone from the Mediterranean. Historical Biology, DOI:10.1080/08912963.2011.621167. 
Hubert, J.F., Panish, P.T., Prostak, K.S., Chure, D.J., 1996. Chemistry, microstructure, 670 petrology, and diagenetic model of Jurassic dinosaur bones, Dinosaur National Monument, Utah. 671 Journal of Sedimentary Research 66, 531-547.

672 Jans, M.M.E., 2008. Microbial bioerosion of bone - a review, in: Wisshak, M., Tapanila L. 673 (Eds.), Current development in Bioerosion. Erlangen Earth Conference Series, pp. 397-413. 674 Jehlička, J., Bény, C., 1992. Application of Raman microspectrometry in the study of structural 675 changes in Precambrian kerogens during regional metamorphism. Organic Geochemistry 18, 211676213.

Jones, W.J., Won, Y.J., Maas, P.A.Y., Smith, P.J., Lutz, R.A., Vrijenhoek, C., 2006. Evolution 678 of habitat use by deep-sea mussels. Marine Biology 148, 841-851.

679 Kaim, A., Kobayashi, Y., Echizenya, H., Jenkins, R.G., Tanabe, K., 2008. Chemosynthesis 680 based associations on Cretaceous plesiosaurid carcasses. Acta Palaeontologica Polonica 53, 97-104. 681 Kano, Y., Chiba, S., Kase, T., 2002. Major adaptive radiation in neritopsine gastropods 682 estimated from 28S rRNA sequences and fossil records. Proceedings of the Royal Society of 683 London B 269:2457-2465.

Kastner, M., 1984. Control of dolomite formation. Nature 311, 410-411.

Kiel, S., 2008. Fossil evidence for micro- and macrofaunal utilization of large nektonfalls: $690273,2625-2631$. 
Kiel, S., Goedert, J.L., Kahl, W-A., Rouse, G.W., 2010. Fossil traces of the bone-eating worm Osedax in early Oligocene whale bones. Proceedings of the National Academy of Science, USA $107,8656-8659$.

Koski, R.A., Lonsdale, P.F., Shanks, W.C., Vemdt, M.E., Howe, S.S., 1985. Mineralogy and geochemistry of a sediment hosted hydrothermal sulfide deposits from the southern trough of the Guaymas Basin, Gulf of California. Journal of Geophysical Research 90, 6695-6707. Kudryavtsev, A.B., Schopf, J.W., Agresti, D.G., Wdowiak, T J., 2001. In situ laser-Raman imagery of Precambrian microscopic fossils. Proceedings of the National Academy of Sciences USA 98, 823-826.

Laetsch, T.A., Downs, R.T., 2006. Software for identification and refinement of cell parameters from powder diffraction data of minerals using the RRUFF Project and American Mineralogist Crystal Structure Databases. Program and Abstracts of the 19th General Meeting of the International Mineralogical Association in Kobe, Japan. P08-25.

Lyman, R.L., 1994. Vertebrate taphonomy. Cambridge University Press, Cambridge. Marshall, C.P., Edwards, H.G.M., Jehlicka, J., 2010. Understanding the application of Raman spectroscopy to the detection of traces of life. Astrobiology 10, 229-243.

Mazzullo, S.J., 2000. Organogenic dolomitization in peritidal to deep-sea sediments. Journal of Sedimentary Research 70, 10-23.

McLoughlin, N., Brasier, M.D., Wacey, D., Green, O.R., Perry, R.S., 2007. On Biogenicity Criteria for Endolithic Microborings on Early Earth and Beyond. Astrobiology 7, 10-26.

Mozley, P.S, Buns S.J, 1993. Oxygen and carbon isotopic composition of marine carbonate concretions: an overview. Journal of Sedimentary Petrology 63, 73-83.

Naganuma, T., Wada, H., Fujioka, K., 1996. Biological community and sediment fatty acids associated with the deep-sea whale skeleton at the Torishima Seamount. Journal of Oceanography $52,1-15$. 
Nesbitt, E.A., 2005. A novel trophic relationship between cassid gastropods and mysticete whale carcasses. Lethaia 38, 17-25.

Pasteris, J.D., Wopenka, B., 2003. Necessary, but not sufficient: Raman identification of

disordered carbon as a signature of ancient life. Astrobiology 3, 727-738.

Paytan, A., Griffith, E.M., 2007. Marine barite: Recorder of variations in ocean export productivity. Deep-Sea Research II 54, 687-705.

Peckmann, J., Thiel, V., 2004. Carbon cycling at ancient methane-seeps. Chemical Geology $205,443-467$.

Pfretzschner, H.U., 2001. Pyrite in fossil bone. Neues Jahrbuch für Geologie und Paläontologie Abhandlungen 220, 1-23.

Pfretzschner, H.U., 2004. Fossilization of Haversian bone in aquatic environments. Comptes Rendus Palevol 3, 605-616.

Pyenson, N.D., Haasl, D.M., 2007. Miocene whale-fall from California demonstrates that cetacean size did not determine the evolution of modern whale-fall communities. Biology Letters (Palaeontology) 3, 709-711.

Raiswell, R., Fisher, Q.J., 2000. Mudrock-hosted carbonate concretions: a review of growth mechanisms and their influence on chemical and isotopic compostion. Journal of the Geological Society, London 157, 239-251.

Riding, R., Tomás, S., 2006. Stromatolite reef crusts, Early Cretaceous, Spain; bacterial origin of in situ-precipitated peloid microspar? Sedimentology 53, 23-34.

Schäfer, W., 1972. Ecology and palaeoecology of marine environments. Chicago, University of Chicago Press.

Schumann, G., Manz, W., Reitner, J., Lustrino, M., 2004. Ancient fungal life in North Pacific Eocene oceanic crust. Geomicrobiology Journal 21, 241-246. 
Senko, J.M., Campbell, B.S., Henriksen, J.R., Elshahed, M.S., Dewers, T.A., Krumholz, L.R., 743 2004. Barite deposition resulting from phototrophic sulfide-oxidizing bacterial activity. Geochimica 744 et Cosmochimica Acta 68, 773-780.

745 Shapiro, R.S., 2004. Recognition of Fossil Prokaryotes in Cretaceous Methane Seep Carbonates:

Relevance to Astrobiology. Astrobiology 4, 438-449.

Shapiro, R.S., Spangler, E., 2009. Bacterial fossil record in whale-falls: Petrographic evidence of microbial sulfate reduction. Palaeogeography, Palaeoclimatology, Palaeoecology 274, 196-203.

Smith, C.R., 2006. Bigger is better: the role of whales as detritus in marine ecosystems, in:

Estes, J.A., De Master, D.P., Brownell Jr., R.L., Doak, D.F., Williams, T.M. (Eds.), Whales, Whaling and Ocean Ecosystems. University of California Press, Berkeley, CA, USA, pp. 286-301. Smith, C.R., Baco, A.R., 2003. Ecology of whale falls at the deep-sea floor. Oceanography and Marine Biology: an Annual Review 41, 311-354.

Smith, C.R., Maybaum, H.L., Baco, A.R., Pope, R.H., Carpenter, S.D., Yager, P.L., Macko, S.A., Deming, J.W., 1998. Sediment community structure around a whale skeleton in the deep Northeast Pacific: macrofaunal, microbial and bioturbation effects. Deep-Sea Research II 45, 335364.

Squires R.L., Goedert J.L., Barnes L.G., 1991. Whale carcasses. Nature 349, 574.

Stamatakis M.G., Hein J.R., 1993. Origin of barite in tertiary marine sedimentary rocks from Lefkas Island, Greece. Economic Geology 88, 91-103.

Torres, M.E., Bohrmann, G., Dubé, T.E., Poole, F.G., 2003. Formation of modern and Paleozoic stratiform barite at cold methane seeps on continental margins. Geology 31, 897-900.

Treude, T., Smith, C.R., Wenzhöfer, F., Carney, E., Bernardino, A.F., Hannides, A.K., Krüger, M., Boetius, A., 2009. Biogeochemistry of a deep-sea whale fall: sulphate reduction, sulfide efflux and methanogenesis. Marine Ecology Progress Series 382, 1-21. 
Trueman, C.N., Martill, D.M., 2002. The long-term survival of bone: the role of bioerosion.

767 Archaeometry 44, 371-382.

768 Turner-Walker, G., 2008. The chemical and microbial degradation of bones and teeth, in:

769 Pinhasi, R., Mays, S. (Eds.), Advances in human paleopathology. Wiley \& Sons, Chichester, pp. 177029.

771 Turner-Walker, G., Nielsen-Marsh, C.M., Syversen, U., Kars, H., Collins, M.J., 2002. Sub772 micron spongiform porosity is the major ultra-structural alteration occurring in archaeological bone. 773 International Journal of Osteoarchaeology 12, 407-414.

774 Veronesi, M., 1997. Analisi sedimentoloigico-stratigrafica sulle Arenarie di M. Vallassa e sulle 775 Arenarie di Serravalle tra Pietravigna (PV) e Gavi (AL). Master thesis, Università degli Studi di 776 Pavia, pp. 139.

777 Wings, O., 2004. Authigenic minerals in fossil bones from the Mesozoic of England: poor 778 correlation with depositional environments. Palaeogeography, Palaeoclimatology, Palaeoecology, 779 204: 15-32. 
Fig. 1. Schematic geological map of the Voghera whale site, Northern Italy. The Voghera whale was recovered within middle Miocene blue-grey sandy marls belonging to the Epiligurid Monte Vallassa Formation (arrow). Oblique lines: areas of outcrop of Alpine units; horizontal lines: areas of outcrop of Apennine units; light-grey: Oligo-Miocene sedimentary successions of Monferrato, Torino Hill and Tertiary Piedmont Basin; dark-grey: Epiligurids; unpatterned: Plio-Pleistocene sediments. Figure modified from Clari et al., 2009.

Fig. 2. The Voghera whale, specimen V658, Civico Museo di Scienze Naturali di Voghera (Italy). The fossil whale bones, vertebrae and ribs, are enclosed in a carbonate concretion A. Upper view of the main block enclosing the bones. B. Lower view of the same block. Note the alignment of the two vertebrae. wb: whale bone; ec: enclosing concretion.

Fig. 3. Transmitted light photomicrographs of petrographic thin sections of the Voghera whale bones and the enclosing carbonate concretion. A. Fossil whale bone (wb) and the enclosing concretion (ec). The enclosing concretion consists of a siliciclastic matrix cemented by microcrystalline dolomite. Note the canals of compact bones (wb) filled by sparry calcite (sc). B. Enclosing concretion with fecal pellets (arrows).

Fig. 4. Raman spectrum of the Voghera whale fossil bones. The bones are preserved as Ca-rich fluoroapatite, $\mathrm{Ca}_{5}\left(\mathrm{PO}_{4}, \mathrm{CO}_{3}\right)_{3} \mathrm{~F}$. 
808 Fig. 5. Transmitted light photomicrographs of petrographic thin sections of the Voghera whale bones. A. Bone structure with well preserved compact and cancellous bone tissue. Note black iron mono sulfides especially concentrated at the compact-cancellous bone interface (arrows). B. Detail of compact bone as observed in cross polarized light. The birefringent pattern of the osteons emphasizes the concentric lamellar structures (arrow) surrounding the central Haversian canal. C. Detail of compact bone showing radial microcracks (small white arrows). The cavities of Haversian canals can be empty (black arrow) or filled with pyrite framboids (large white arrow).

D. Well preserved osteocyte cells (arrow) within the carbonate-rich fluoroapatite fossil bone. E. Globular lepidocrocite (arrows) in the bone matrix. All figures in plane polarized light except $\mathrm{C}$ which is cross polarized.

Fig. 6. Transmitted light photomicrographs and SEM images of petrographic thin sections showing trabecular bones (boxed area). Sparry calcite (sc) occludes the voids. B. Detail (magnification of the boxed area in $\mathbf{A}$ ) of an aggregate of micropeloids (arrows). The micropeloids are stained by opaque Fe-sulfides (py: pyrite) and -oxyhydroxides (lep: lepidocrocite) . C. High magnification of one micropeloid. Micropeloids consist of a microcrystalline dolomite nucleus (md) surrounded by small rhomoboedral dolomite crystals (arrow) lining bone trabecula (wb), and cemented with sparry calcite (sc). E. Detail of the micropeloid (high magnification of boxed area in D). Note the clotted 
(3-5 $\mu \mathrm{m})$ microcrystalline dolomite (md) and the well developed rhombohedra on the external part (arrows). F. Pyrite framboids (py) partially oxidized into lepidocrocite (lep) and closely associated with small rhombohedral dolomite (rd). Note the internal area of framboids with still preserved pyrite microcrystallites. A, B, and C in plane polarized light.

Fig. 7. Transmitted light photomicrographs of petrographic thin sections showing rosette-like cements lining whale bones. A. Rosette-like structures (white arrows) close to bone trabeculae and embedded in sparry calcite. Rosette-like structures occur typically as isolated and paired bodies, or in small aggregates. At the top note clotted dolomite (cd) embedded in the sparry calcite cement. Note also the osteocytes (black arrow) within the whale bone. B. Detail of rosette-like structures formed by few small pyrite framboids (py) surrounded by rhombohedral dolomite crystals.

Fig. 8. Raman spectra of the carbonate cements filling cancellous bones and of pyrite-lepidocrocite framboids. A. Raman spectral signature of rhombohedral dolomite crystals and sparry calcite. B. Raman spectral signature of pyrite and lepidocrocite minerals. Note the presence of well-defined D $\left(1350 \mathrm{~cm}^{-1}\right)$ and $\mathrm{G}\left(1600 \mathrm{~cm}^{-1}\right)$ peaks associated with both the dolomite crystals and pyrite, indicating the presence of disordered carbonaceous matter (DCM).

Fig. 9. Transmitted light photomicrographs of petrographic thin sections showing Type 1 microborings in cancellous and compact bones. A. Trabeculae of cancellous bones (wb) intensely bored by Type 1 microborings (arrows). Cancellous bones are filled with clotted dolomite (cd), micropeloids (mp) and sparry calcite (sc). B. Detail of Type 1 microborings within trabecular 
bones. They do not show any preferential orientation. C. Type 1 microborings in compact bone.

This image shows an intensively bioeroded area (300 $\mu \mathrm{m}$ thick) which is tunneled with a pattern that follows the micro-architecture of the bone tissue. Note in fact that the bioeroded area is delimited by bright cement lines (arrows) that mark the boundaries between the secondary osteons of the Haversian systems. D. Detail of the intensively bioeroded compact bone. The Haversian canal contains a reddish lepidocrocite grain (arrow). Note that bioerosion totally obliterate the concentric lamellae typical of the osteons. All figures in plane polarized light.

\section{Fig. 10. Transmitted light photomicrographs of petrographic thin sections showing Type 2} microborings in compact bones. A. Type 2 microborings on the external side of the compact bone.

Note the $90^{\circ}$ bifurcations (arrows). B. Detail of Type 2 microborings. Note the reddish lepidocrocite grains forming central swellings (small arrows) and a sack-shaped swelling at the tip of the same filament (large arrow). C. The arrow point to a bifurcating microboring containing two small reddish lepidocrocite grains which highlight internal segmentation. D. Bifurcating Type 2 microborings (small arrows). Note the large aperture linking one tunnel to the outside of the bone (large arrow). The black dotted line delimits the external side of the bone.

Fig. 11. SEM images of the bioeroded bones. A. External surface of compact bones showing a 200 $\mu \mathrm{m}$ thick zone intensively bioeroded by Type 1 microborings. B. Detail of Type 1 microborings in cancellous bones. The microborings resemble empty tunnels with micron-sized mineral grains encrusting the walls (arrows). C. EDX analysis of the micron-sized Fe-oxide grains arrowed in B. Both apatite in the bone and the Fe-oxide were detected in this analysis. D. Barite crust covering the external surface of bones. Note the intensely bioeroded bones. E. Detail of the barite crust showing 
881 its massive microcrystalline habit. F. EDX analysis of the barite crust. Barite is associated with Sr882 rich calcite. A and $\mathrm{E}$ were made in backscattered electron mode, $\mathrm{C}$ and $\mathrm{D}$ in secondary electron 883 mode with an acceleration voltage of $15 \mathrm{kV}$.

886 Fig. 12. Stable isotope analyses of the carbonate cements inside and outside the Voghera whale 887 fossil bones. Cross-plot of $\delta^{13} \mathrm{C}$ and $\delta^{18} \mathrm{O}$ values of dolomite filling cancellous bones (triangles), 888 concretionary dolomite enclosing the bones (squares) and sparry calcite (rhombi). 


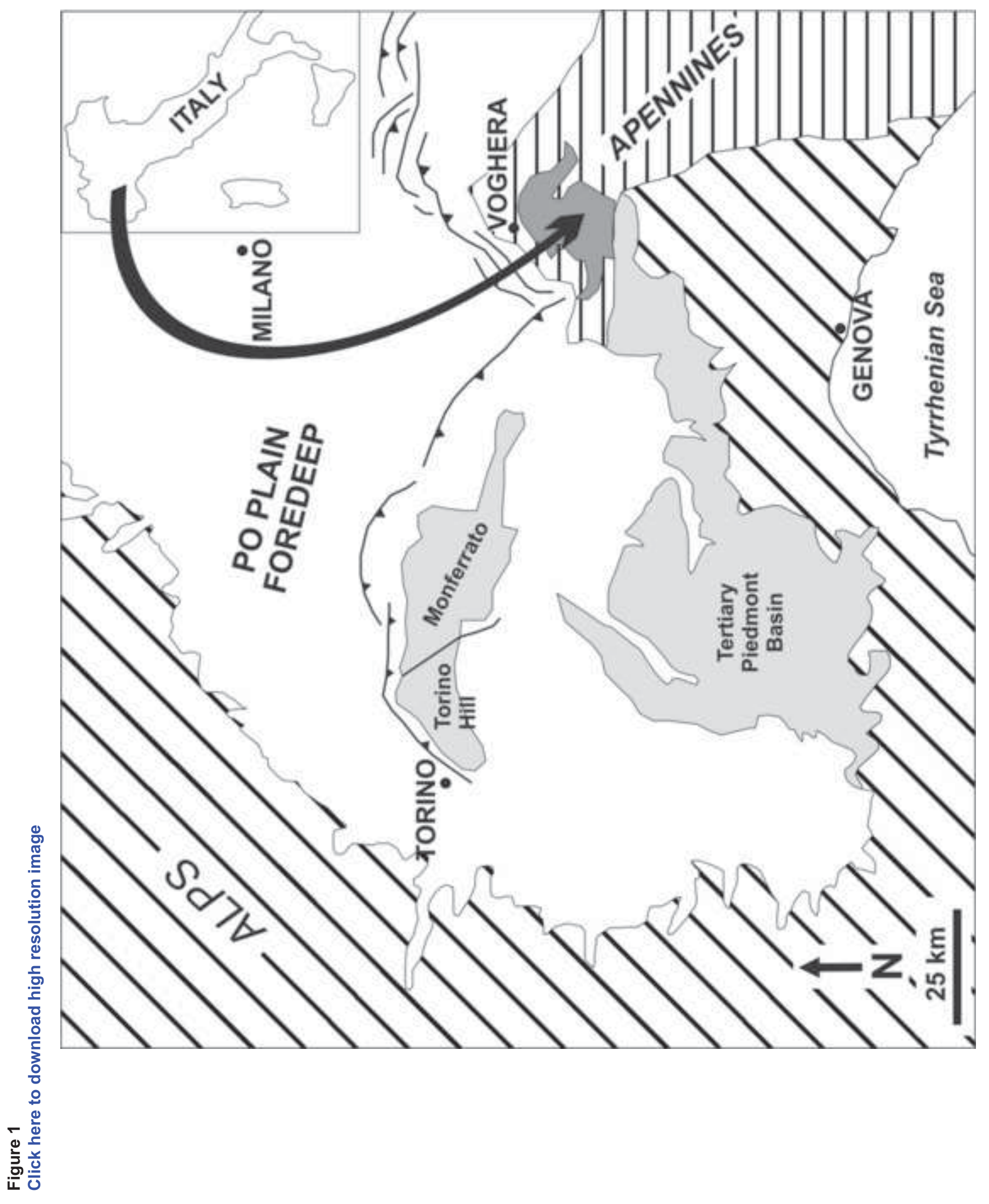



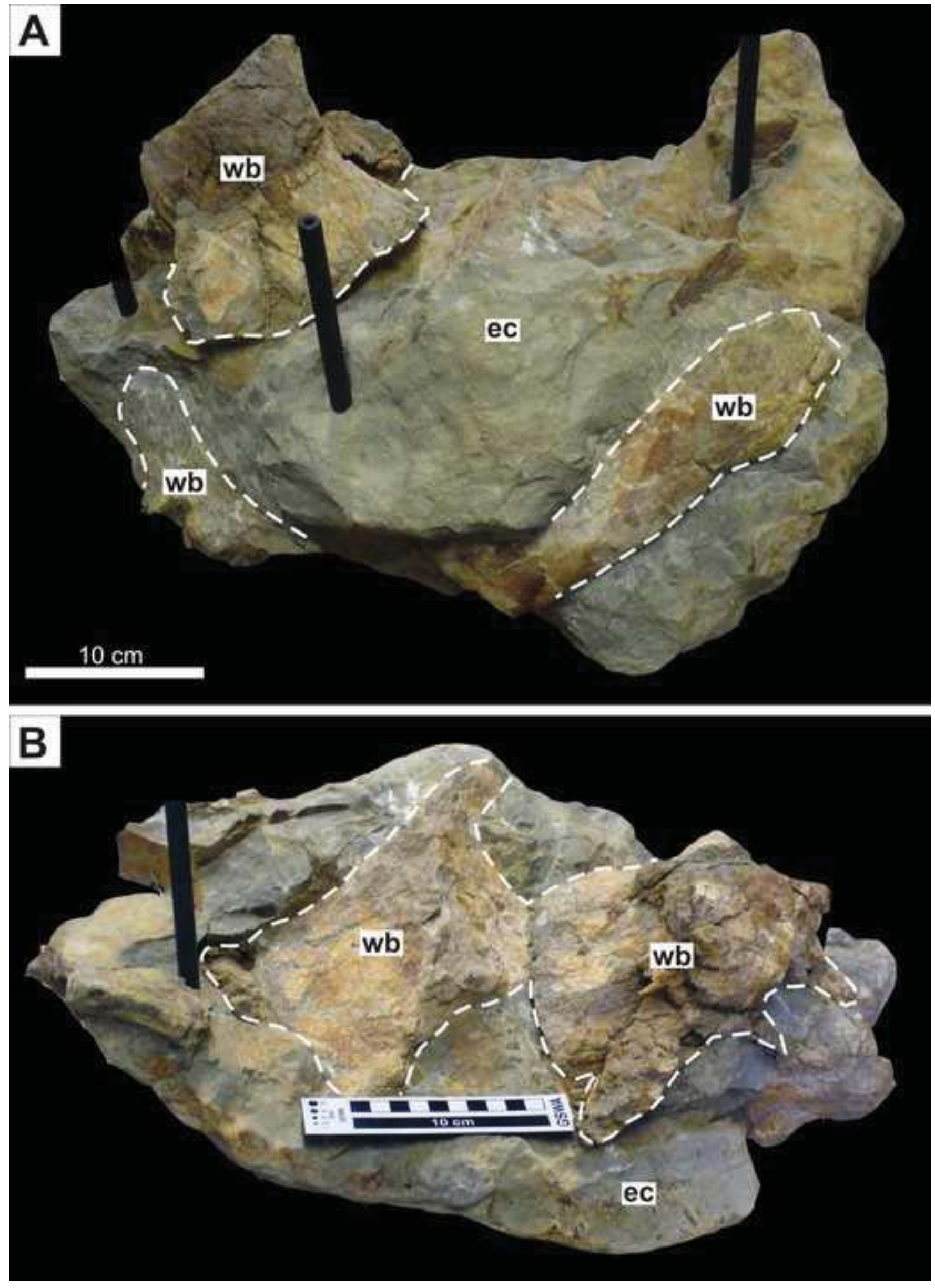

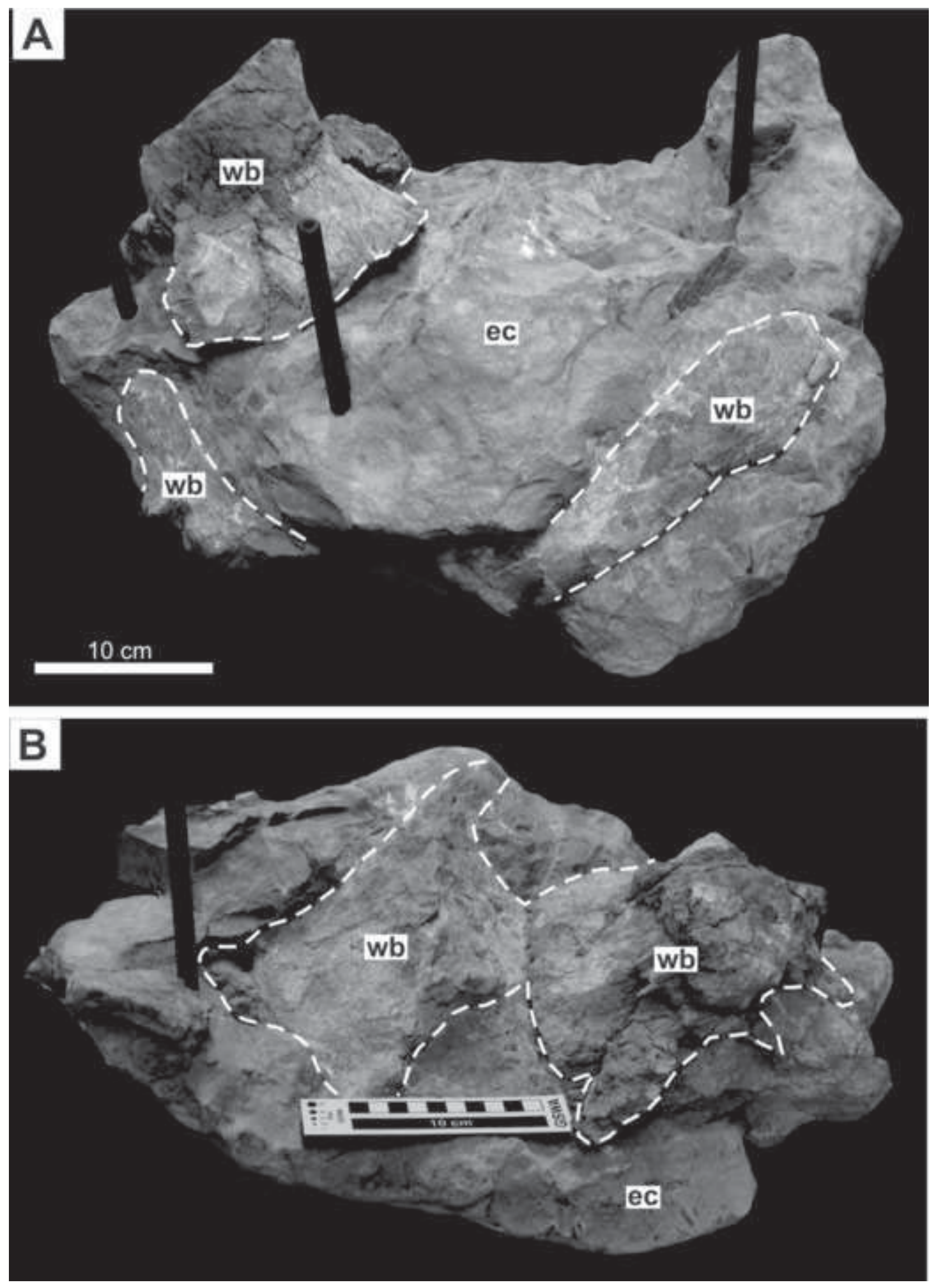


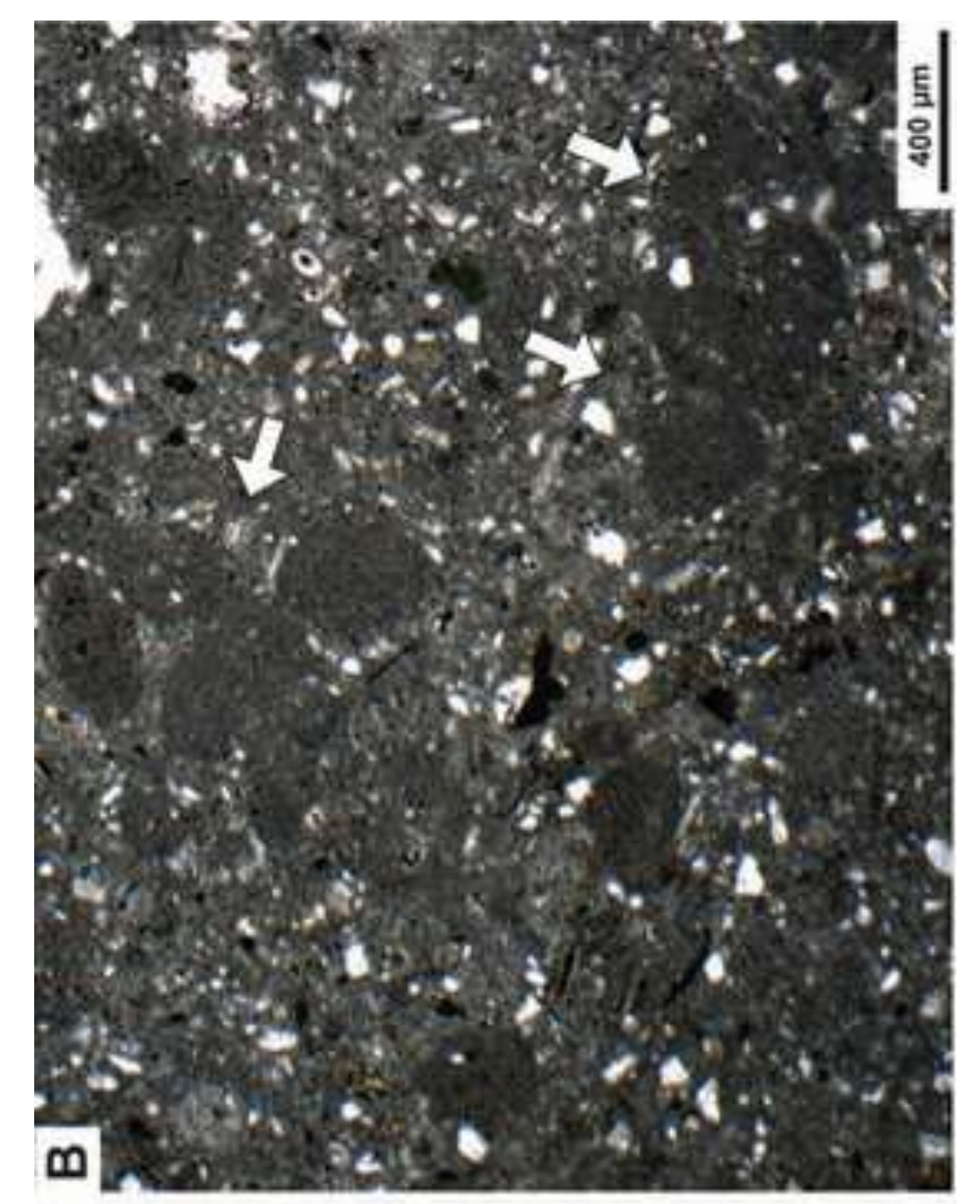

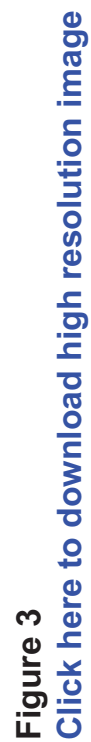

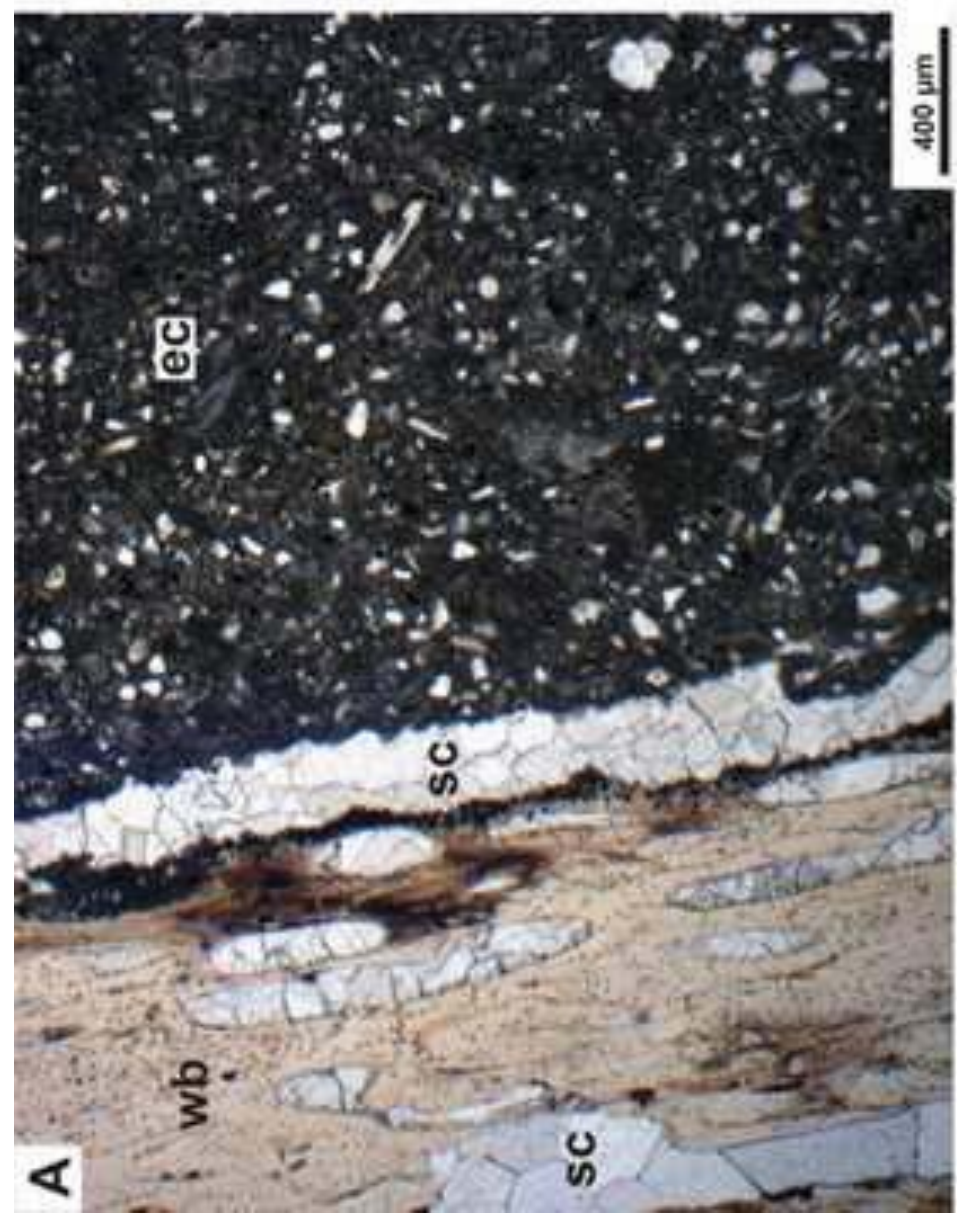




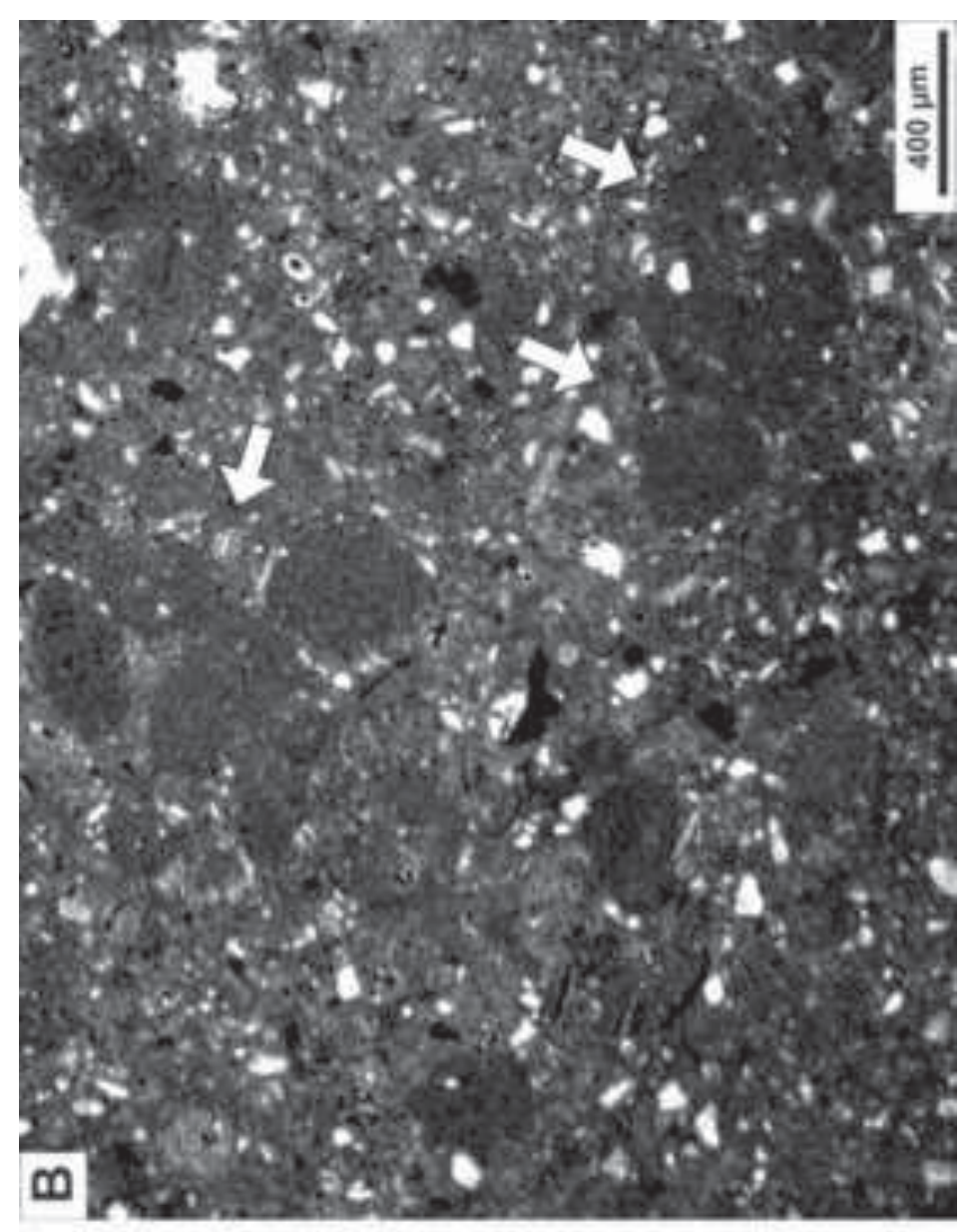

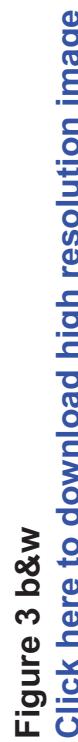

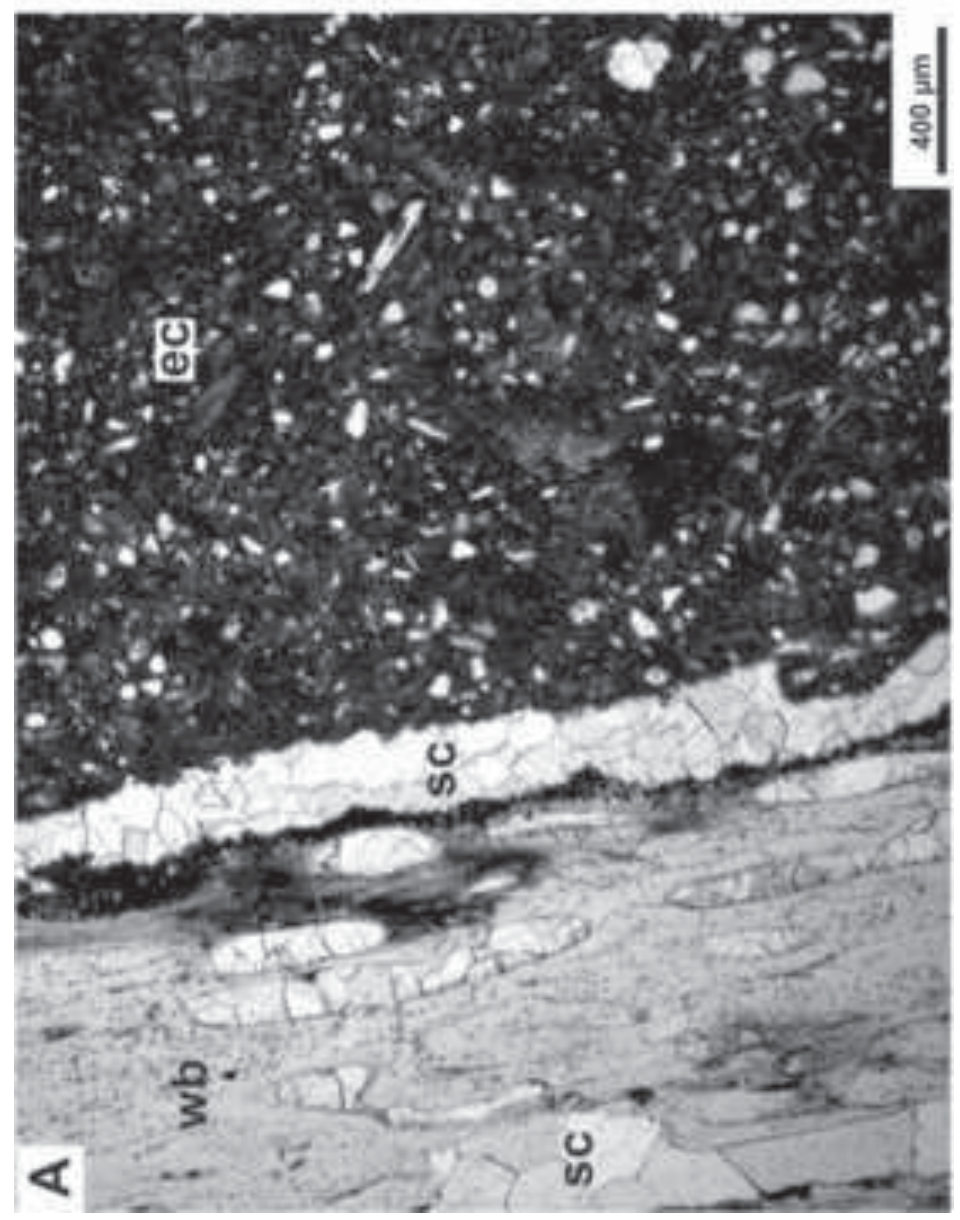




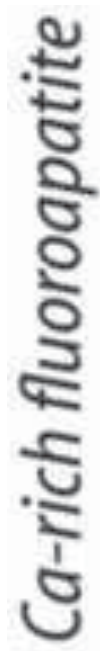

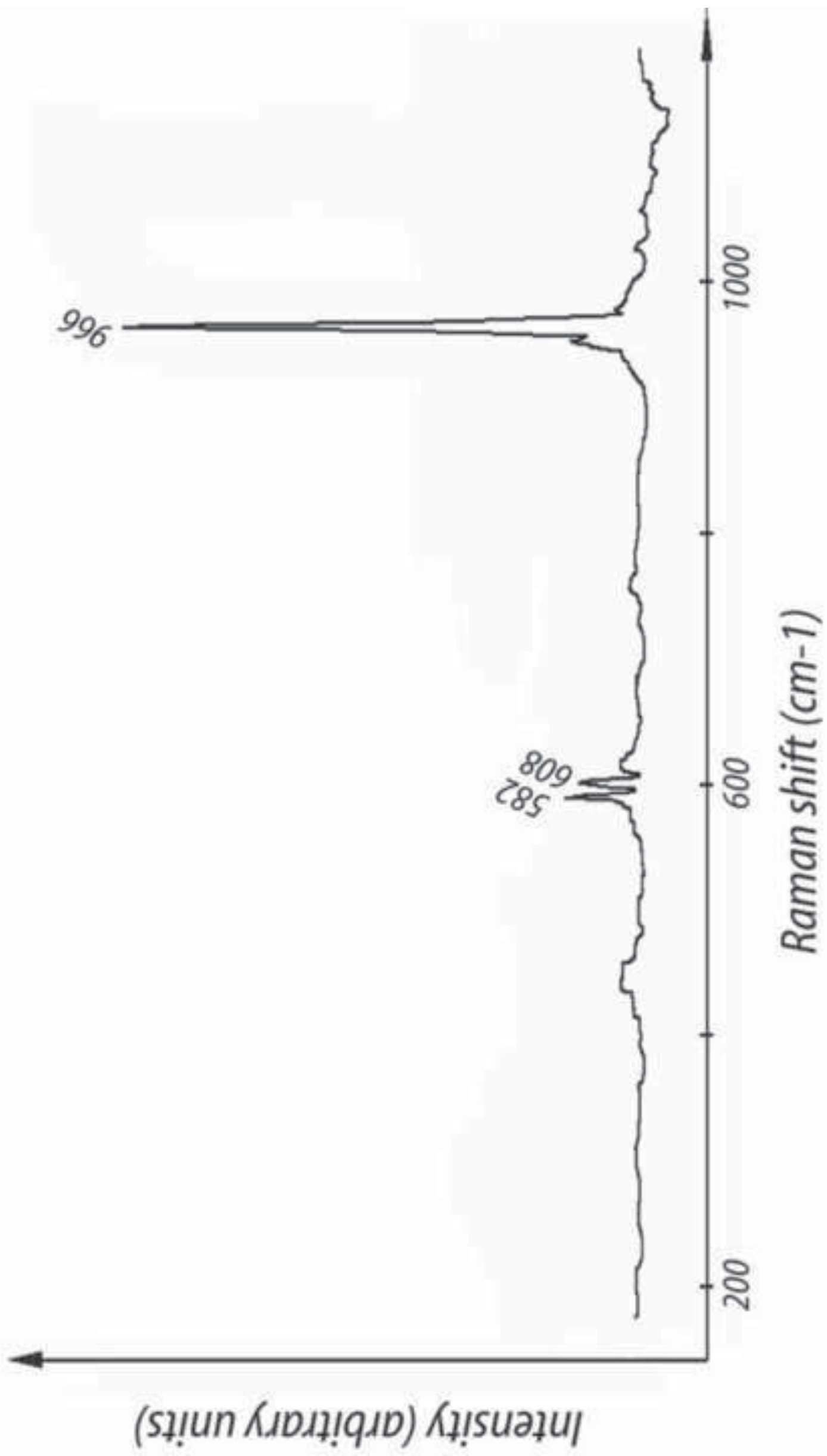

\begin{tabular}{l}
0 \\
\hline \\
\hline \\
\hline
\end{tabular} 
Figure 5

Click here to download high resolution image
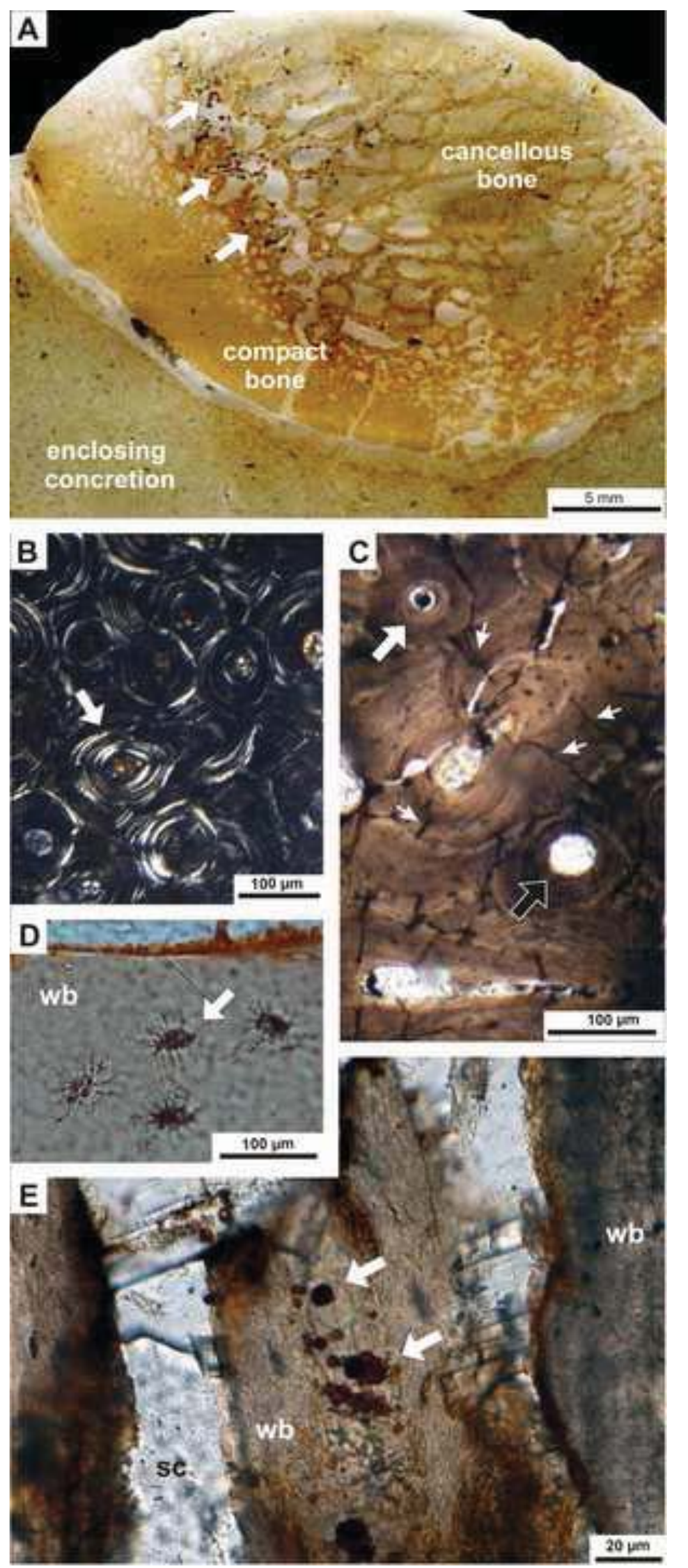

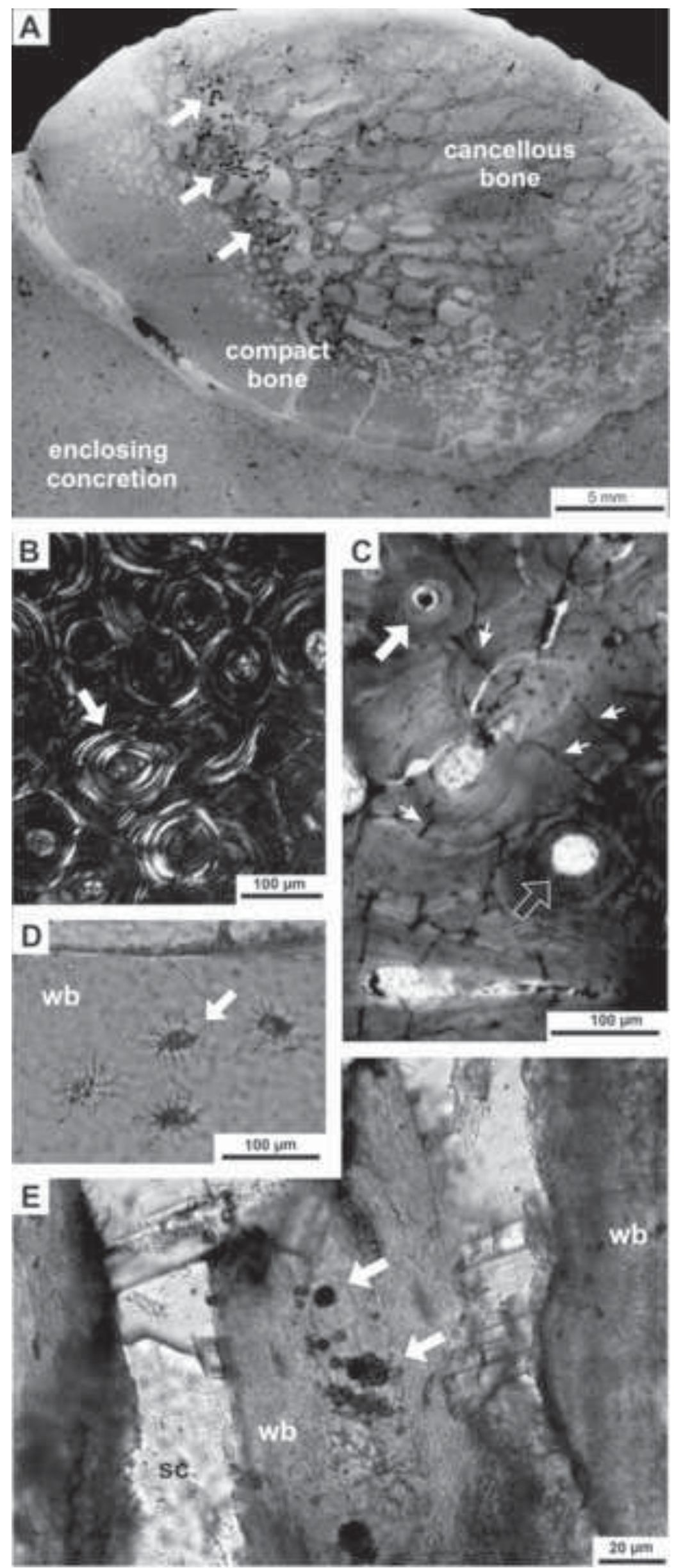


\section{Figure 6}

Click here to download high resolution image
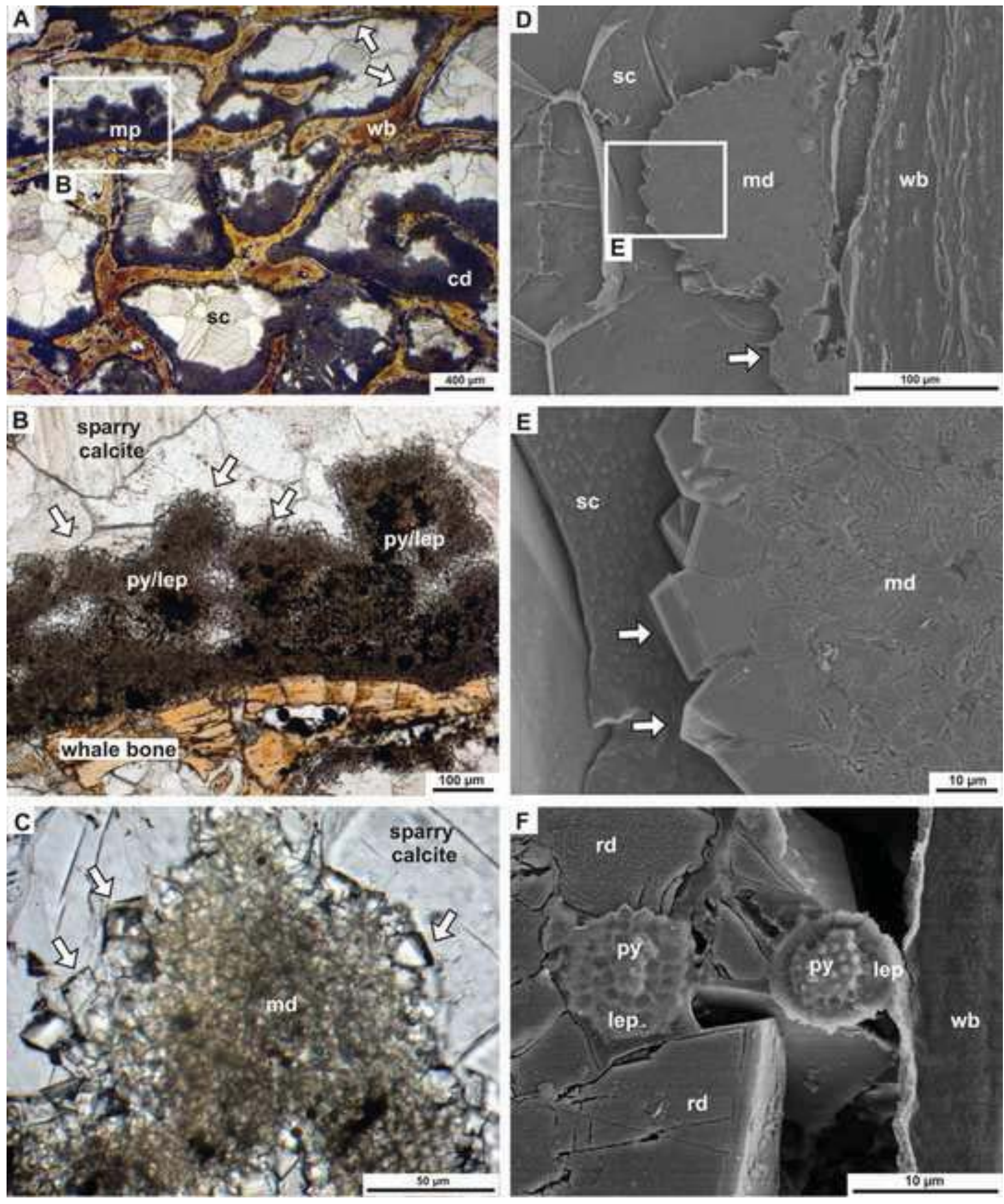

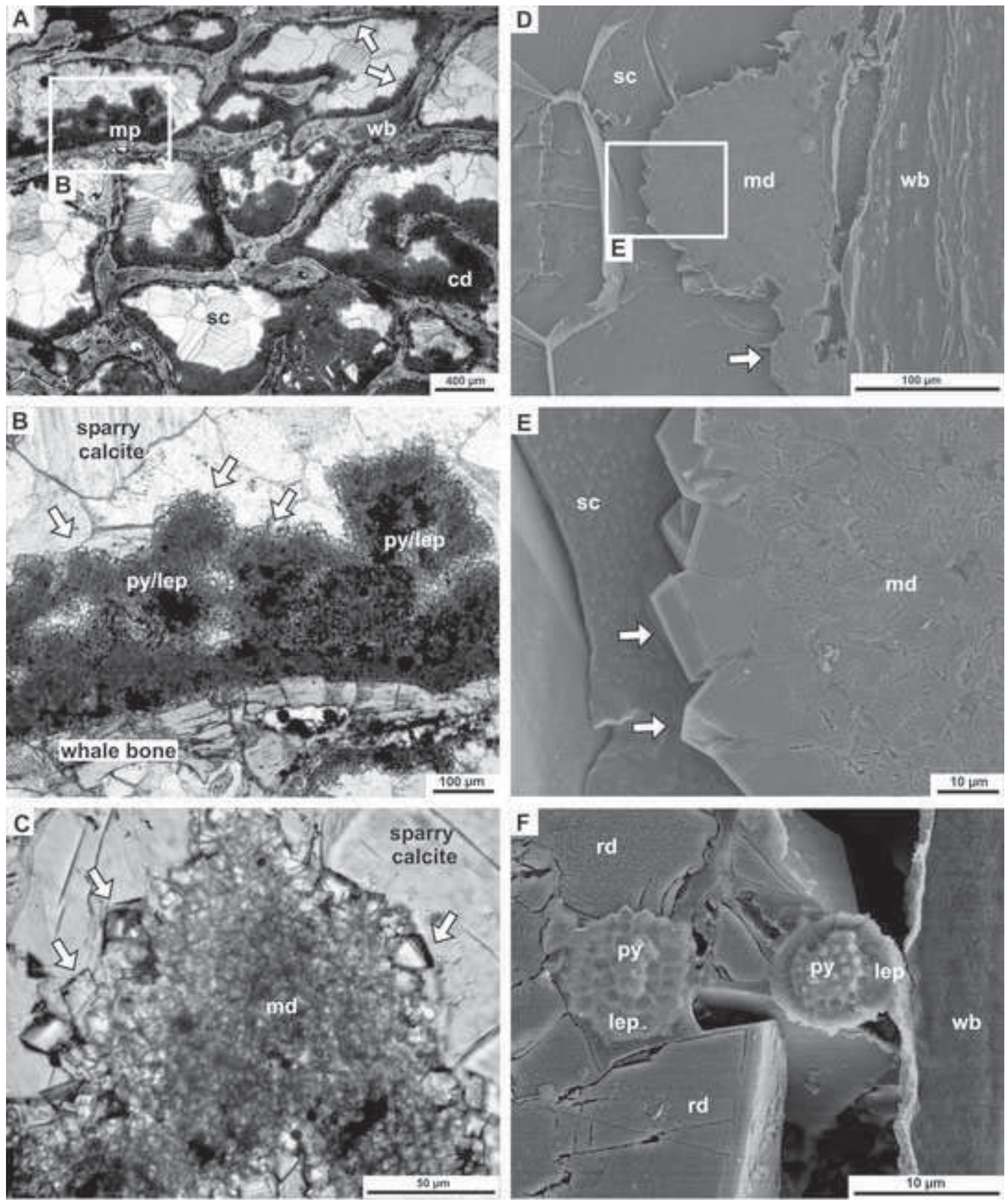


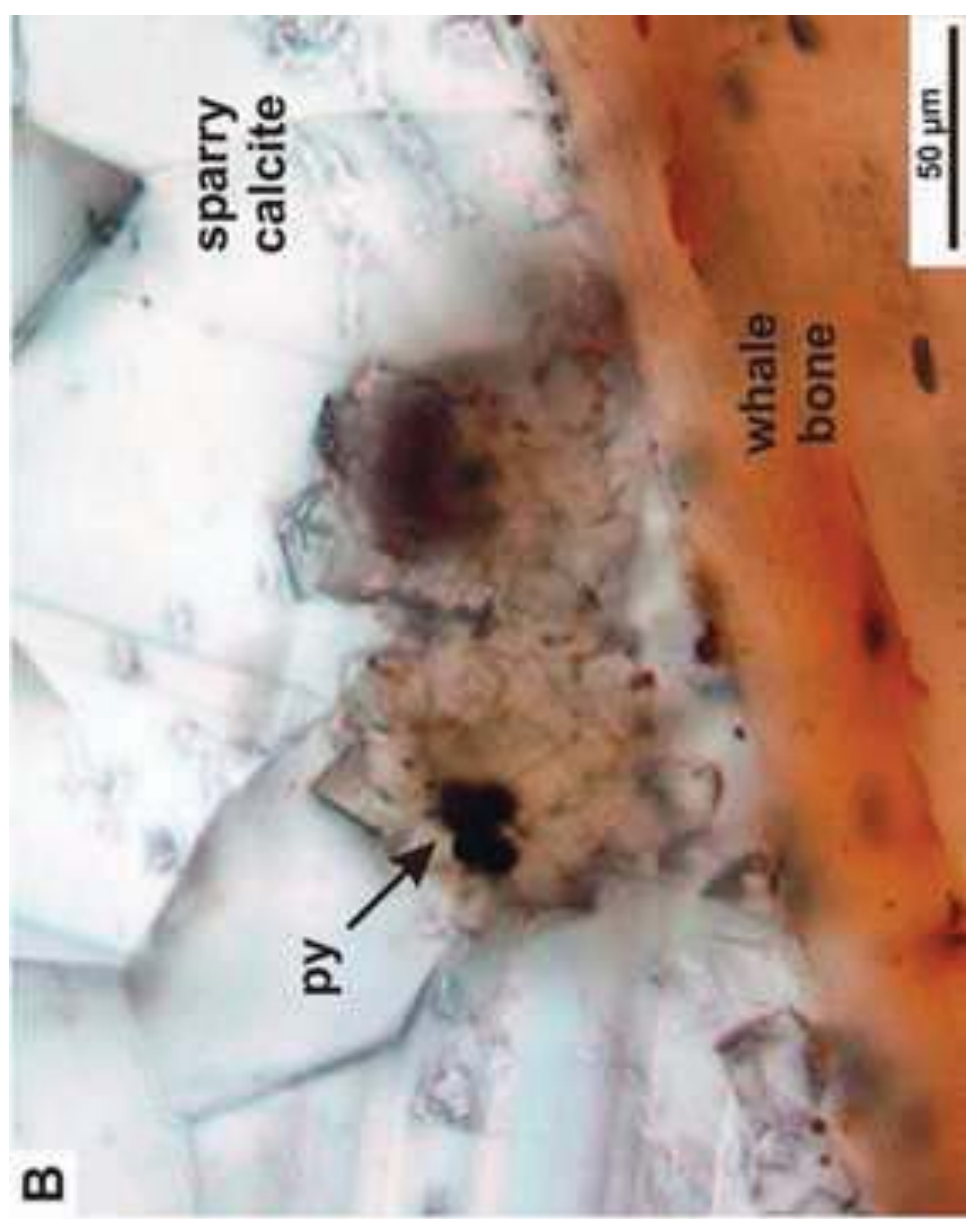

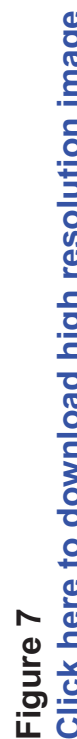

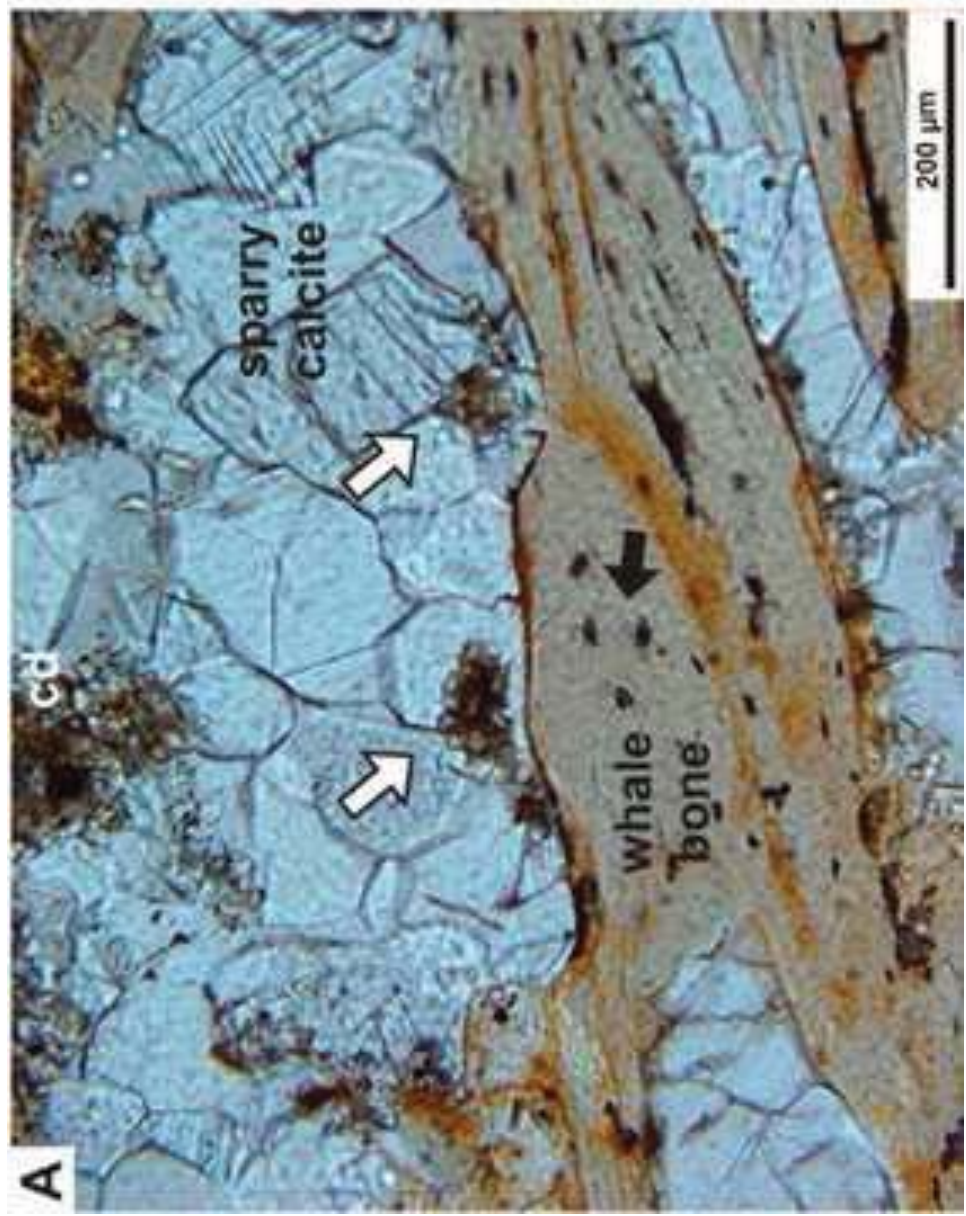




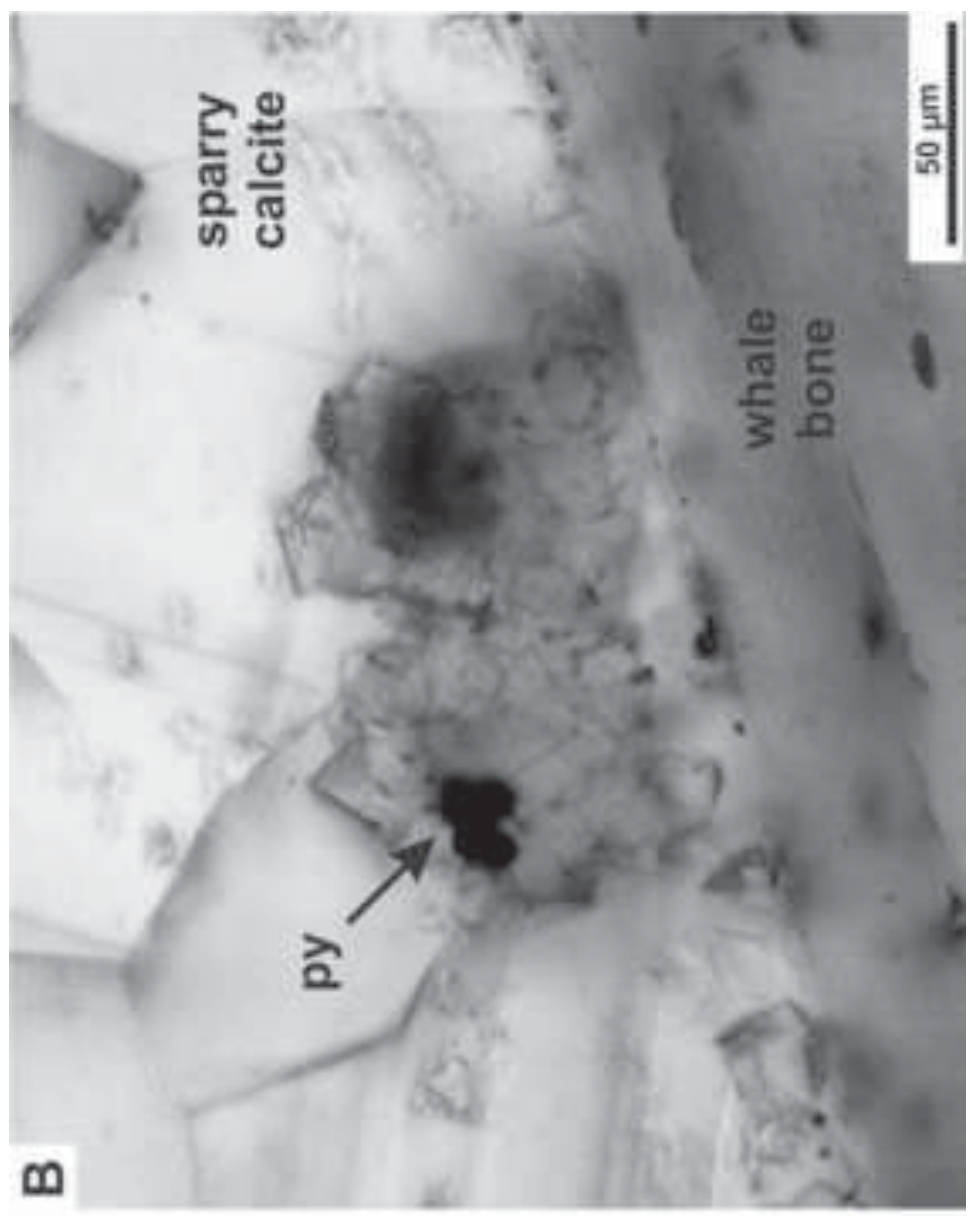

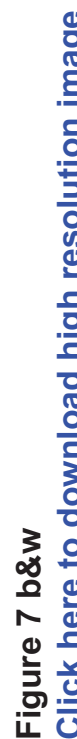

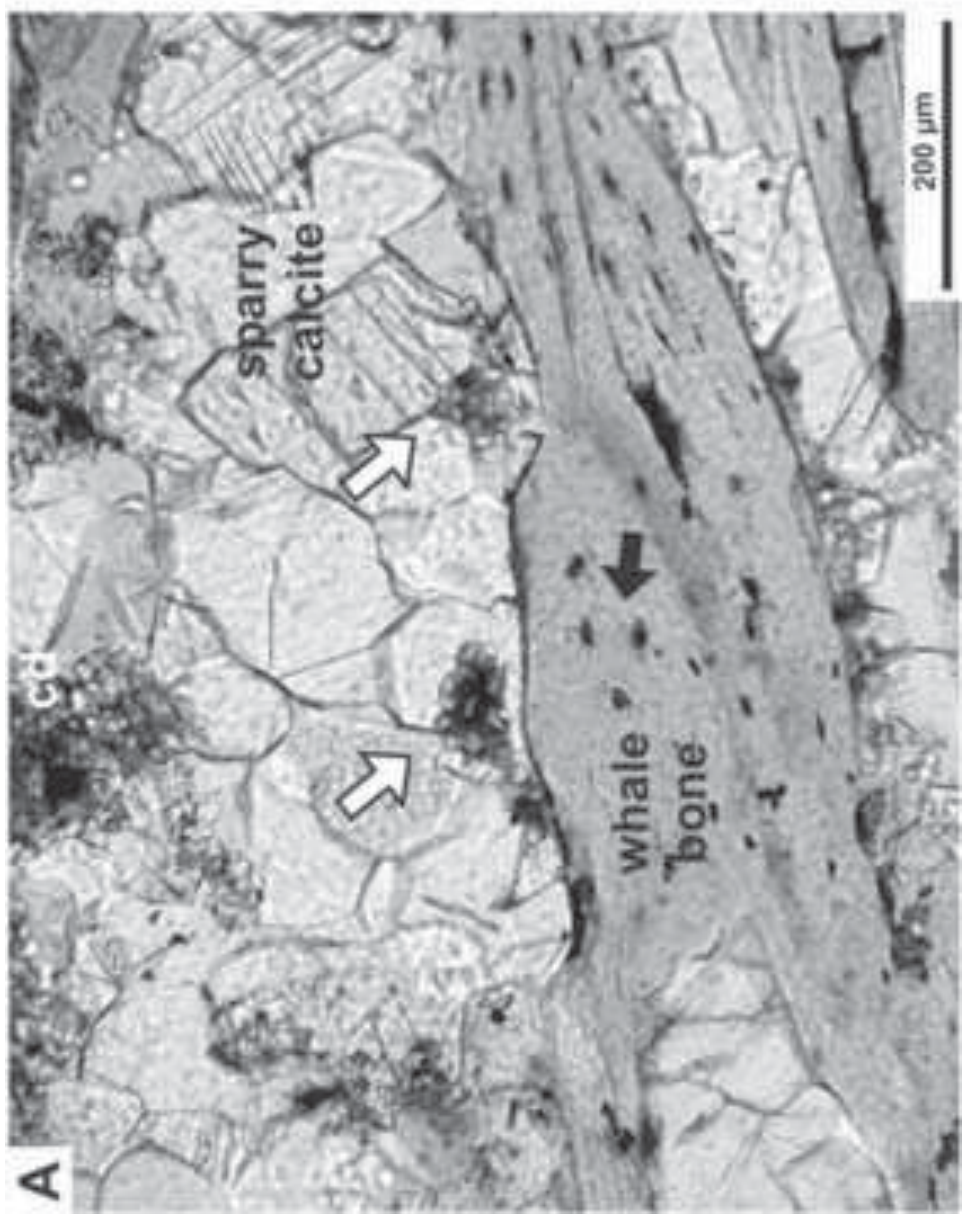



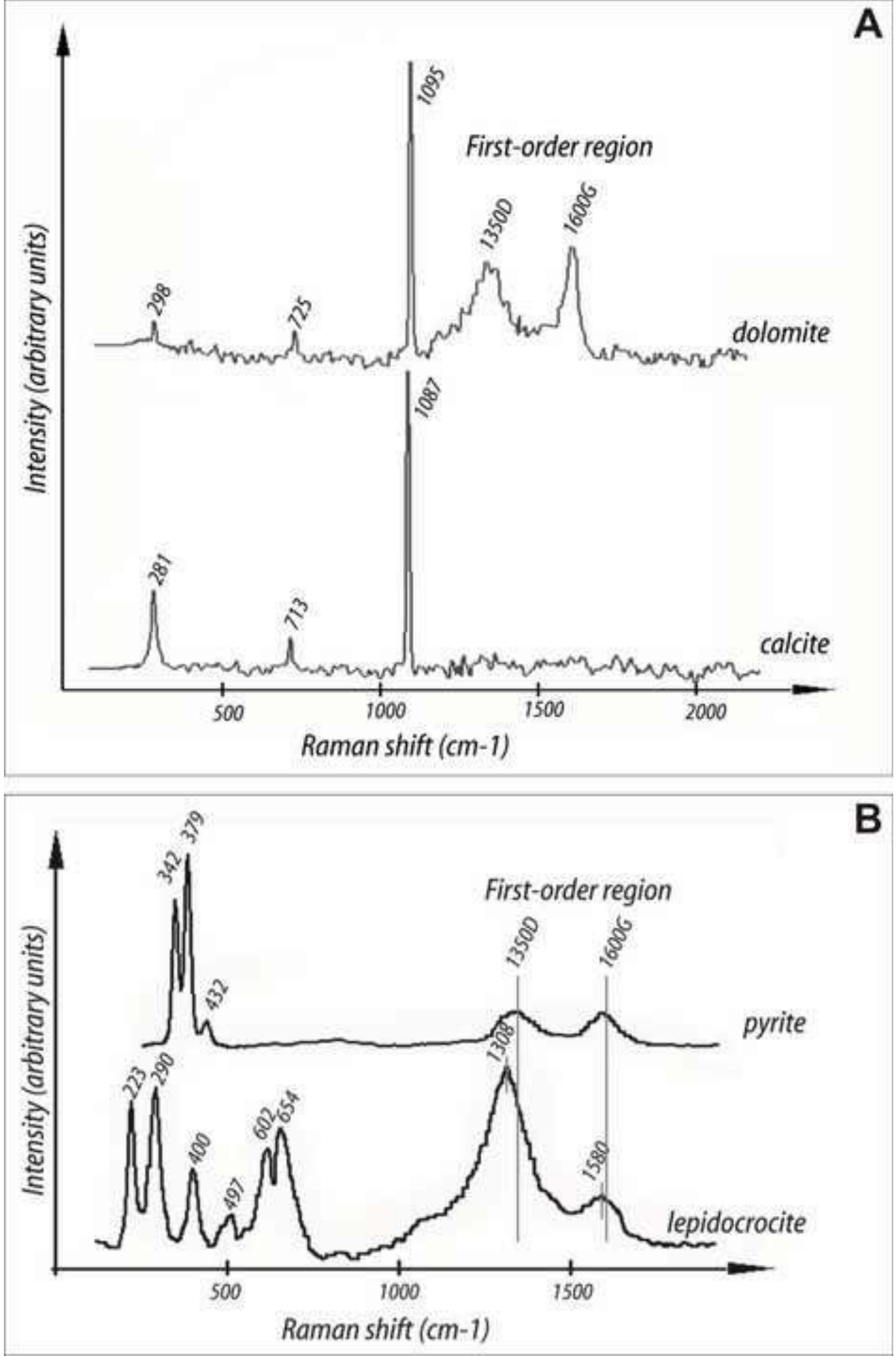

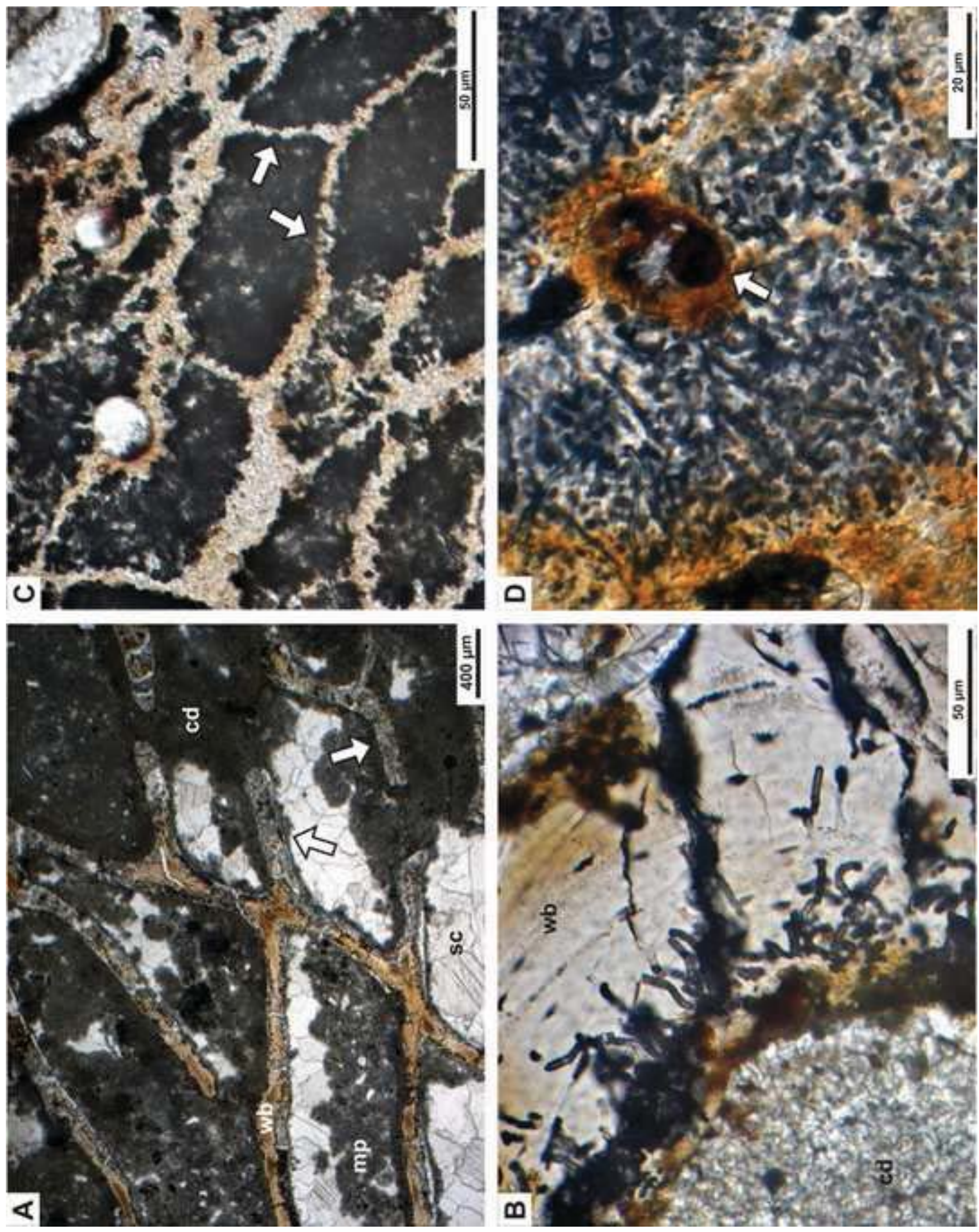

09

总 

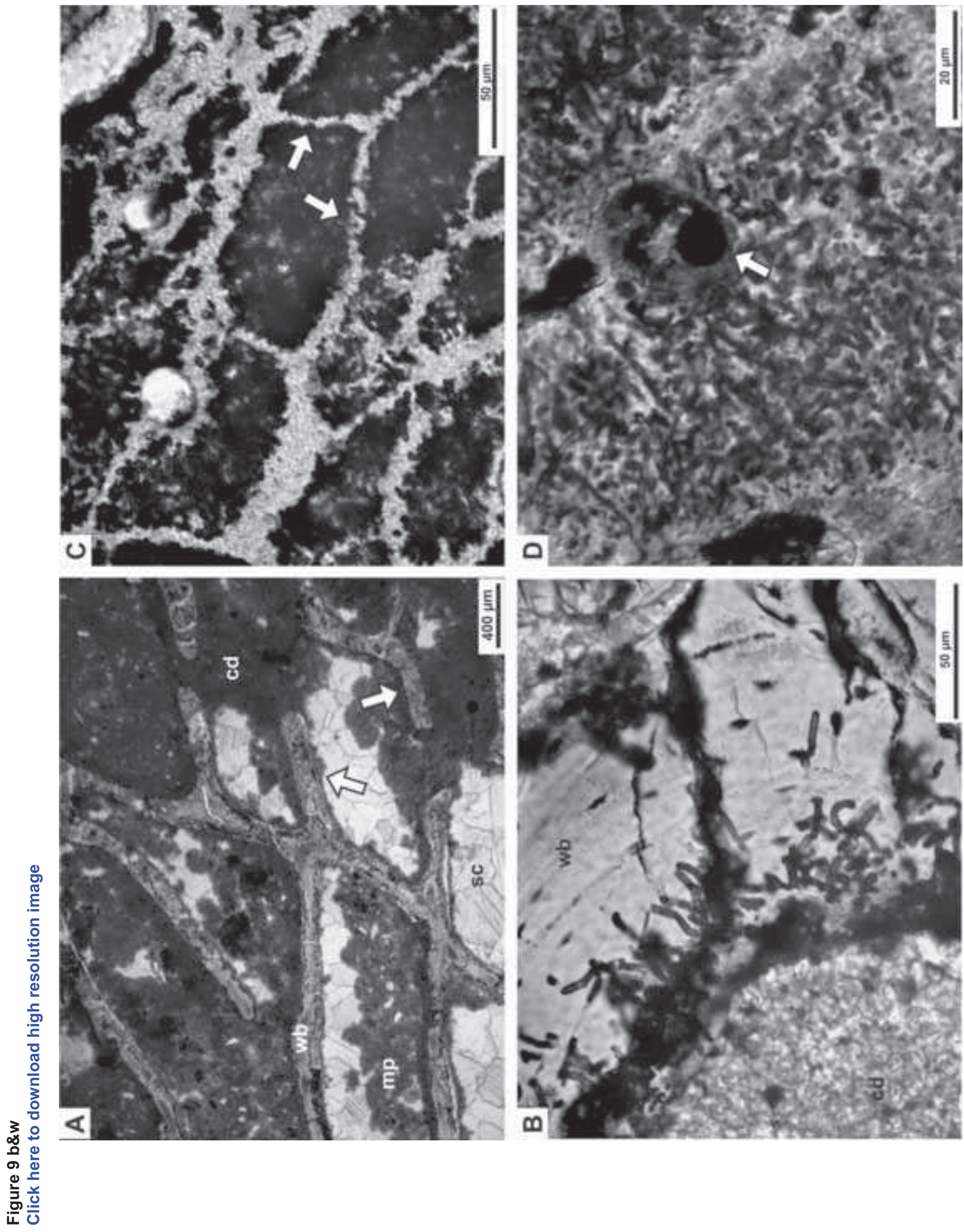

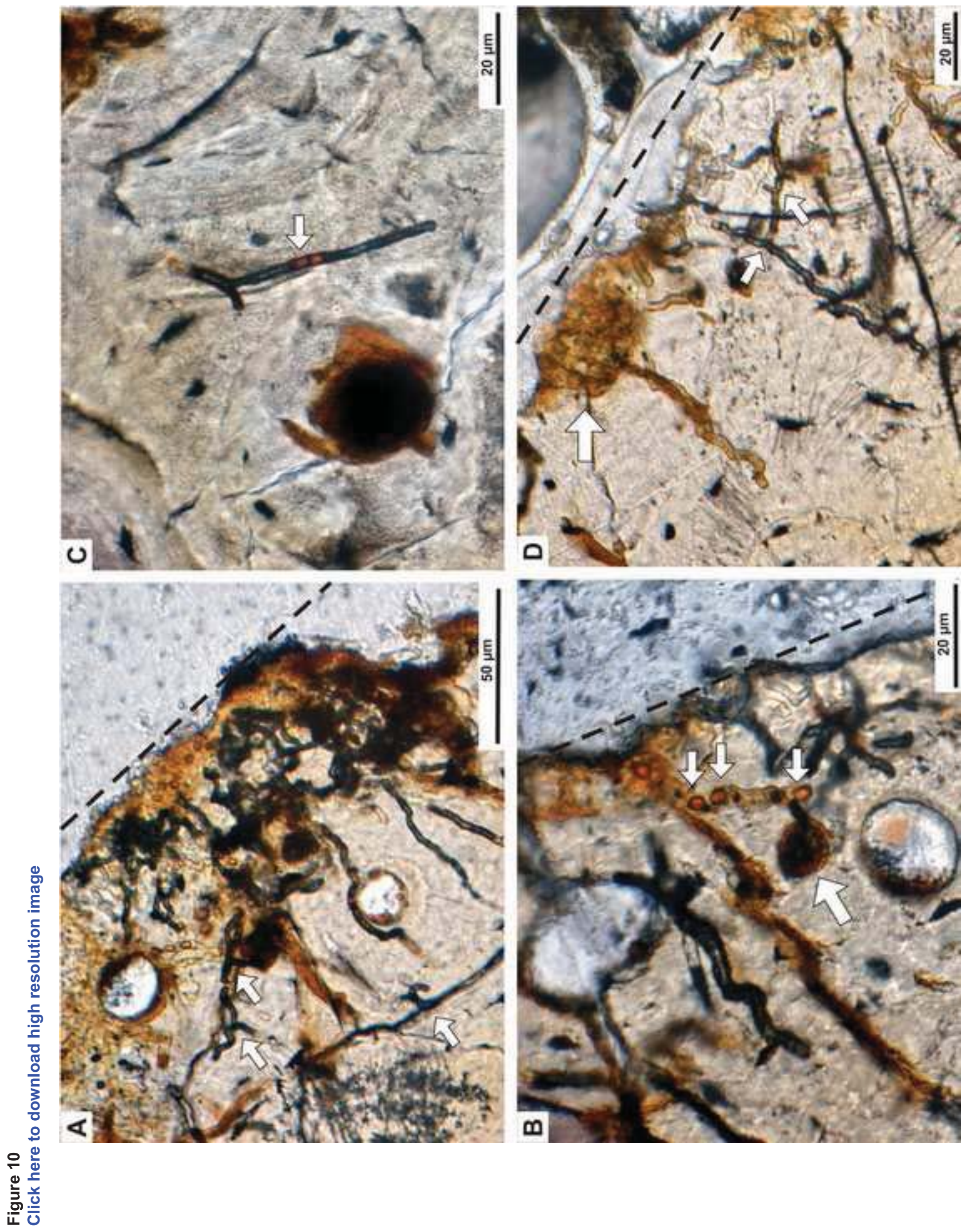

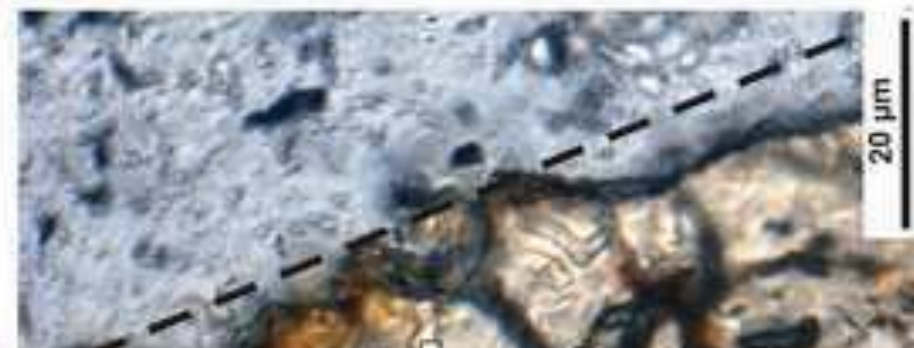

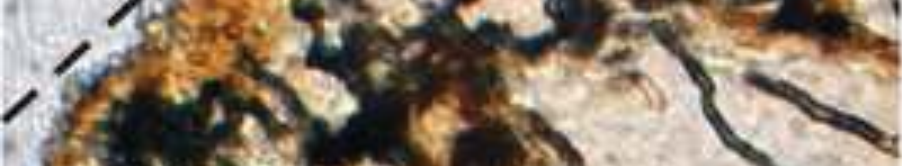

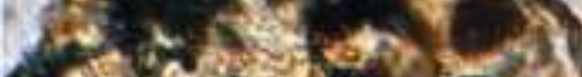
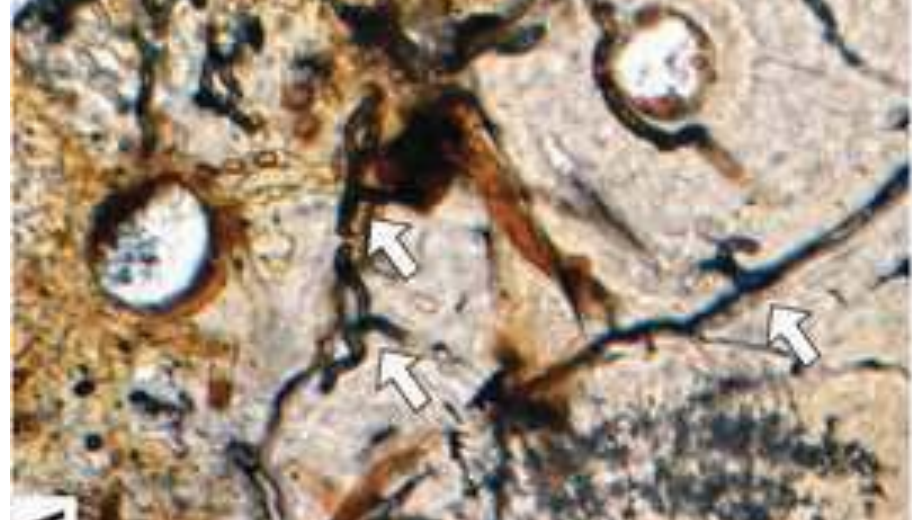

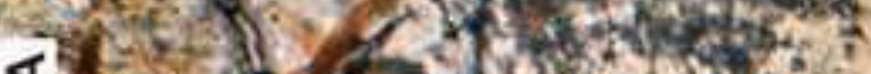

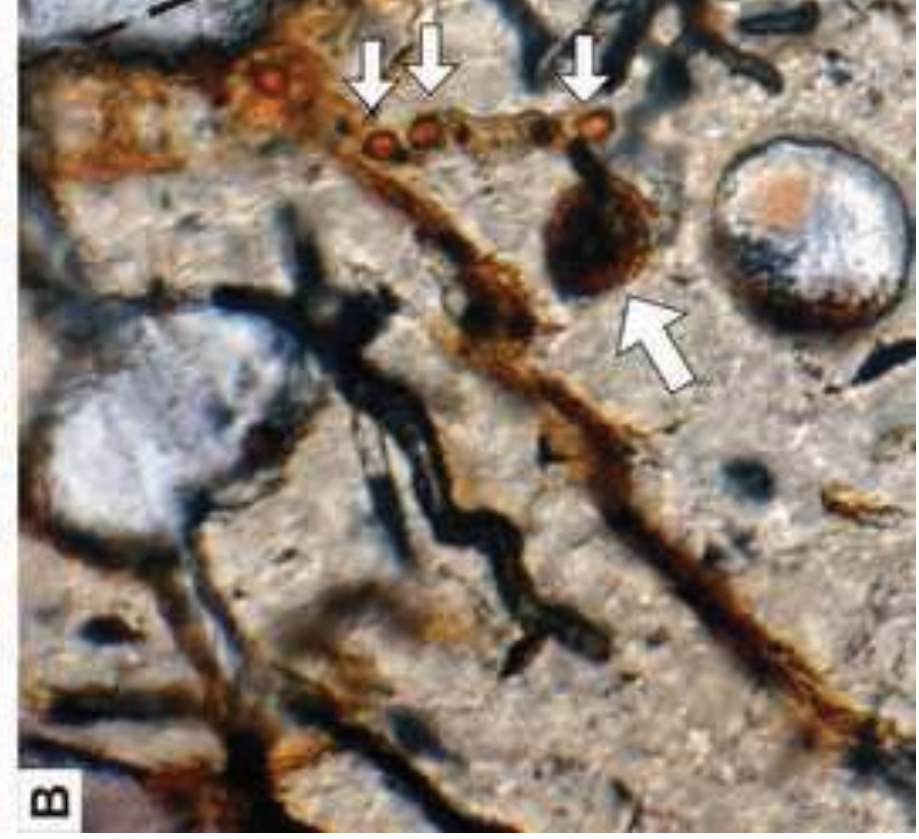



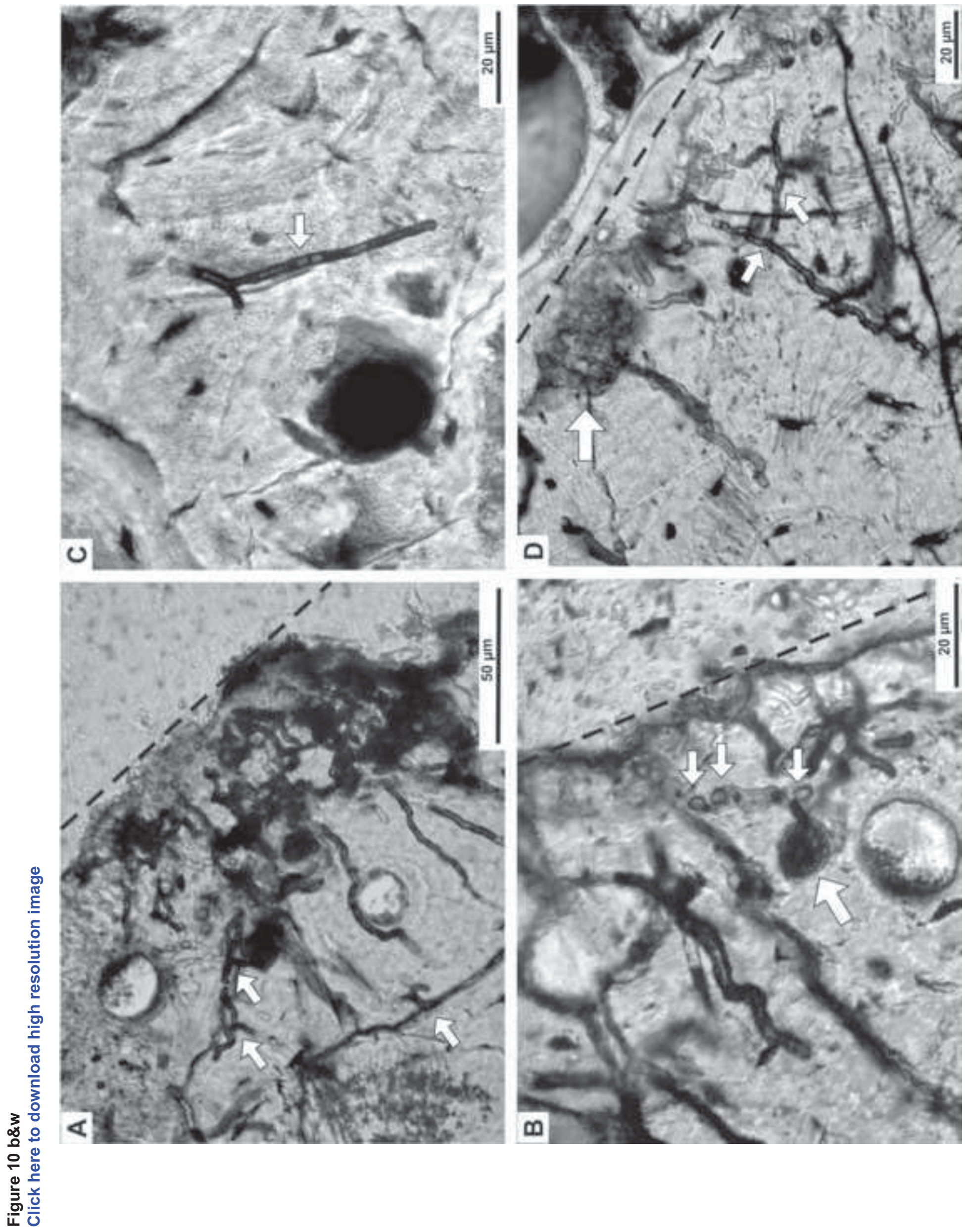

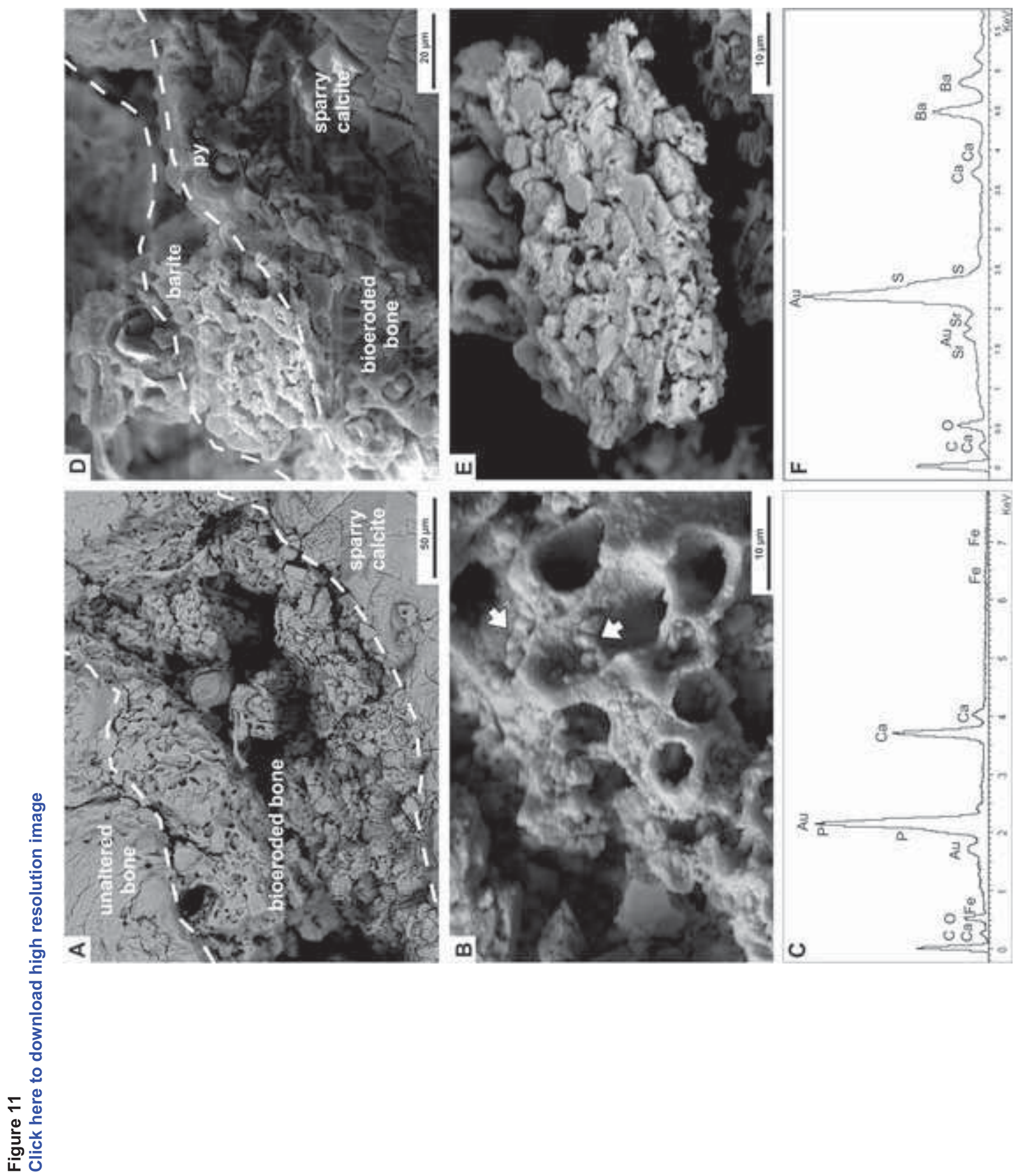

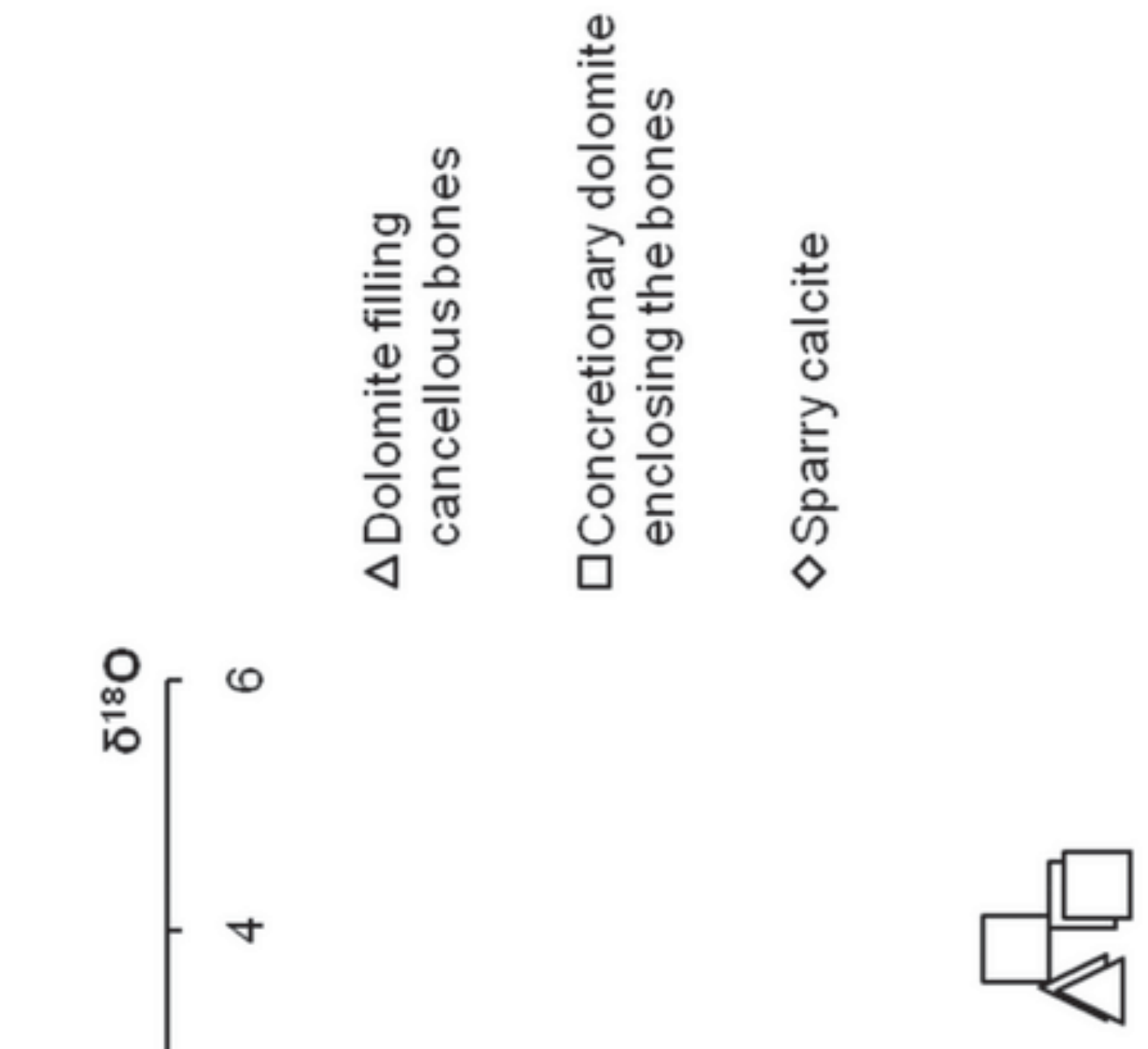